\title{
Articles
}

\section{FIRING THOREAU: CONSCIENCE AND AT-WILL EMPLOYMENT}

\author{
James A. Sonne*
}

It is a virtual axiom of the American workplace that, absent a contract or express law to the contrary, "an employer may terminate an employee at any time, for any reason or no reason at all." Indeed, this presumption of "at-will" employment, which prevails in forty-nine states and the District of Columbia, ${ }^{2}$ has been the law of the land for more than a century. ${ }^{3}$ Rooted in freedom of contract and private property principles, the rule is designed to yield efficiencies across a broad range of industries. ${ }^{4}$ Despite the prominence of at-will power, however, a growing (and potentially contradictory) trend in employment law, particularly in the health care field, is that employees should be protected in the exercise of their consciences-even if such exercise is contrary to their employers' wishes or the demands of their jobs. ${ }^{5}$ This "conscience clause" movement is

* Associate Professor, Ave Maria School of Law. B.A., Duke University; J.D., Harvard Law School. The author thanks George Remy and Jeffrey Melville for their research; Professors Richard Myers, Lynn Wardle, and Robert Vischer for their insights; Mary and Margaret Grace Sonne for their encouragement; and Ave Maria for its support.

1. Cynthia L. Estlund, Labor, Property, and Sovereignty After Lechmere, 46 STAN. L. REv. 305, 312 (1994).

2. See Peter O. Hughes, Labor and Employment LaW (MB) $\S 259.02$ n.5 (2006) (observing "[e]mployment is presumed to be at will in . . . every state" except Montana). For the District of Columbia, see Dantley v. Howard University, 801 A.2d 962, 964 (D.C. 2002) (stating that in the District of Columbia, "an employer may discharge an at-will employee at any time for any reason, or for no reason at all").

3. See generally Jay M. Feinman, The Development of the Employment at Will Rule, 20 AM. J. LEGAL HIST. 118 (1976) (discussing the origins and history of the at-will presumption in American employment).

4. See Richard A. Epstein, In Defense of the Contract at Will, 51 U. CHI. L. REV. 947, 953-58 (1984) (contemplating the practical and theoretical principles underlying the at-will presumption).

5. See Ralph Nader \& Alan Hirsch, A Proposed Right of Conscience for Government Attorneys, 55 HASTINGS L.J. 311, 318-26 (2003) (discussing the rise of conscience rights in American employment). 
admittedly built on other express exceptions to at-will power begun decades ago in the 1960s' Civil Rights era. ${ }^{6}$ And yet, it goes beyond the general, status-based prejudices regulated chiefly by Title VII of the Civil Rights Act of 1964 (Title VII) ${ }^{7}$ and into the arena of an employee's subjective, personal choices that, unlike prominent Title VII criteria like race or gender, may more readily conflict with the legitimate expectations of his or her employer.

Given this recent rise of conscience in a labor environment that still presumes at-will power, the predictable clash of worker and employer interests has become a pressing concern. For example, should a hospital nurse who opposes a doctor's treatment decision be permitted to refuse assistance to a patient seeking the treatment, yet insist on continued employment? $^{8}$ While some jurisdictions say no, increasingly more are saying yes. ${ }^{9}$ Or, as featured more prominently in the press as of late, should a pharmacist who opposes contraception have a right to work, yet not offer birth control pills in a store that would otherwise sell them? ${ }^{10}$ Some jurisdictions say no, but again, more and more are saying yes." To

6. See generally Deborah A. Ballam, Employment-At-Will: The Impending Death of a Doctrine, 37 AM. Bus. L.J. 653 (2000) (discussing limits placed on at-will power beginning in the 1960s). See also Lynn D. Wardle, Protecting the Rights of Conscience of Health Care Providers, 14 J. LEGAL MED. 177, 178 (1993) (using the phrase "conscience clause" to describe, among other things, a conscience-based at-will exception).

7. 42 U.S.C. $\S 2000$ e (2000). Title VII of the Civil Rights Act of 1964 prohibits, inter alia, employment discrimination on the basis of "race, color, religion, sex, or national origin." Id. $\S 2000 \mathrm{e}-2(\mathrm{a})(1)$.

8. See, e.g., Bruce G. Davis, Defining the Employment Rights of Medical Personnel Within the Parameters of Personal Conscience, 1986 DET. C.L. REv. 847, $851-59$ (1986) (discussing cases involving the medical profession with respect to the "public policy" exception to at-will employment).

9. Although many states "focus[] almost exclusively on objection to abortion" in protecting conscience, the trend is towards more global coverage, as reflected by recent statutes in Mississippi, Illinois, and Washington, and bills pending in numerous other states. Jessica J. Nelson, Comment, Freedom of Choice for Everyone: The Need for Conscience Clause Legislation for Pharmacists, 3 U. ST. THOMAS L.J. 139, 149-50 (2005). The Mississippi law, which was passed in 2004, covers refusals "to participate in a[ny] health care service that violates [one's] conscience." MISS. CODE ANN. § 41-107-5(1) (West 2005). The Illinois law, which was most recently amended in 1998, covers any "health care services contrary to [one's] conscience." 745 ILL. COMP. STAT. ANN. $70 / 7$ (West 2002). Finally, the statute that was passed in Washington in 1995 protects "object[ions]" to health care "for reason of conscience or religion." WASH. REV. CODE ANN. § 70.47.160(2)(a) (West 2002).

10. See generally Robert K. Vischer, Conscience in Context: Pharmacist Rights and the Eroding Moral Marketplace, 17 STAN. L. \& POL'Y REV. 83 (2006) (discussing the virtues of allowing the marketplace to influence the conscience policies for pharmacists in the filling of pharmaceutical prescriptions).

11. See Dennis Rambaud, Note, Prescription Contraceptives and the Pharmacist's Right to Refuse: Examining the Efficacy of Conscience Laws, 4 CARDOZO PUB. L. POL'Y \& ETHICS J. 195, 196 (2006) (discussing a 1998 South Dakota law that protects a pharmacist's 
be sure, in such scenarios, both the employer and employee could invoke their own "rights" to economic or personal freedom, with a pitched battle of wills a very likely result. ${ }^{12}$ Although the full extent of such a clash has yet to be felt, descriptions of its future, such as "a huge national issue,", "a wave that's going to break," serious legal and cultural crisis may be looming. Is such a result inevitable? Should one or the other side yield? Is compromise possible? Answers to such dilemmas are admittedly not self-evident, nor are they expected to be universally accepted when competing, and worthy, values are at stake. And yet, answers are needed, not only for strong labormanagement relations, but also for the proper balancing of personal and corporate interests in society at large. Liberty, conscience, dignity, and free competition are all important ideals, but they do not arise in a vacuum. Indeed, in a pluralistic society, finding a just and workable balance between them is an indispensable task. ${ }^{16}$ And, perhaps more than in any other area of common life, save the government itself, the workplace is where the greatest impact of such balance (or not) is felt. ${ }^{17}$

At present, much of the scholarship on conscience in employment is confined to constitutional or statutory mandates for employee behavior, with a particular emphasis on the common religious dimension of the issues in context. ${ }^{18}$ This article, instead, looks not so much at constitutional

refusal to dispense arguable abortifacients and then observing, "[i]n 2004, at least thirteen state legislatures introduced similar bills, and other states may soon follow suit").

12. See Rob Stein, Pharmacists' Rights at Front of New Debate, WaSH. Post, Mar. 28, 2005, at Al (describing the heated nature of the political conflicts raised by the exercise of conscience in the pharmacy context).

13. Monica Davey \& Pam Belluck, Pharmacies Balk on After-Sex Pill and Widen Fight in Many States, N.Y. TIMES, Apr. 19, 2005, at Al (quoting conscience advocate Paul Caprio, director of Family-Pac).

14. Stein, supra note 12 , at Al (quoting conscience advocate Steven H. Aden in the pharmacy context).

15. Dahlia Lithwick, Wal-Mart and the Death Penalty, WASH. POST, Feb. 26, 2006, at B3.

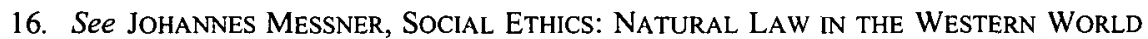
171-72 (J.J. Doherty trans., B. Herder Book Co. 2d ed. 1965) (1958) (discussing the necessity of the "social" balancing of individual and collective values in the laws of any society).

17. See Ballam, supra note 6, at 657 (quoting Frank TANNENBaUm, A Philosophy of LABOR 9 (1951) for the proposition that the workplace has become perhaps the most important relationship in modern society, such that "[w]e have become a nation of employees").

18. See, e.g., Nora O'Callaghan, Lessons from Pharaoh and the Hebrew Midwives: Conscientious Objection to State Mandates as a Free Exercise Right, 39 CREIGHTON L. REV. 561 (2006) (analyzing constitutionality of contraceptive mandates); Lorraine Schmall, Birth Control as a Labor Law Issue, 13 DUKE J. GENDER L. \& POL'Y 139 (2006) (discussing "conscience clauses" largely in constitutional realm); Susan J. Stabile, State Attempts to Define Religion: The Ramifications of Applying Mandatory Prescription Contraceptive 
questions, but to the law of work, and rather than the "heavy hand" of the state, offers the interests of employers and the marketplace as potential counterweights to the individual. There is no doubt that such forces can often seem, and at times are, stronger than the state, and in that sense might even point all the more to an uncompromising sheltering of individual conscience in law. ${ }^{19}$ Despite such a risk of injustice, however, many of the values prized by such entities (e.g., private property, free competition, market efficiency) should not be neglected in the process, whether in pursuit of the common good, or, for that matter, in the securing of personal rights.

In short, this article contends that no protection of employee conscience is proper without a due consideration of the countervailing employer interests in at-will authority. There is no question that the moral arguments supporting a deep respect for conscience in the workplace are compelling, and many, including this author, advocate strongly for the accommodation by employers of human dignity in all its forms, including in the exercise of conscience at work. And yet, the challenge herein is not to the moral dimension of the debate on conscience accommodation, but rather to the resolution of that debate by the law-a challenge which, incidentally, extends in like manner to contrasting mandates that would otherwise inhibit employers from so accommodating. Perhaps in the unique areas of abortion or euthanasia, where the relevant parties invariably perceive their respective positions as non-negotiable, the use of legal means would be appropriate. ${ }^{20}$ However, the issue still remains whether legally requiring employers to accommodate the consciences of their employees on a more global scale strikes a proper balance of the interests of the respective parties, whether as a normative matter or in a manner consistent with how such interests have otherwise been recognized in culture and law. In the end, it is argued here that the growing conscience trend is simply out of sync with any such balance.

In addressing the foregoing, this article proceeds in five parts. Part I offers a brief overview of the relevant dilemma. Part II describes the origin and development of the at-will doctrine and summarizes the current state of the law. Part III, which forms the bulk of the article, studies the rise of the conscience clause movement and explores the ways in which this trend has

Coverage Statutes to Religious Employers, 28 HARV. J.L. \& PUB. POL'Y 741 (2005) (elucidating state mandates).

19. See Lawrence E. Blades, Employment at Will vs. Individual Freedom: On Limiting the Abusive Exercise of Employer Power, 67 CoLUM. L. REv. 1404, 1404 (1967) ("It is a widely accepted proposition that large corporations now pose a threat to individual freedom comparable to that which would be posed if governmental power were unchecked.").

20. See Pope John Paul 1I, The Gospel of Life [Evangelium Vitae] $\mathbb{7 4}$ (Vatican trans., Random House 1995) (1995) (addressing legal and moral aspects of conscientious objection in abortion and euthanasia contexts). 
taken place (particularly in the workplace) and the degree to which it is consistent (or not) with the treatment of conscience in law and culture generally. Part IV explores the respective interests and values of employers and employees at issue in the at-will-conscience dichotomy, and proposes a framework for balancing such interests and values, both for their own sake and in the best interests of the workplace and society as a whole. Part V closes with a brief conclusion. On the whole, this article does not provide a panacea. Rather, it examines the relevant values at stake and strives to strike a balance that maximizes the rights and duties of both the individual and the community in the very real economic, legal, and social contexts in which modern work is performed.

\section{GREETING THE "CRISIS" ${ }^{21}$-AN OVERVIEW}

Although the significance of conscience in American public life (i.e., vis-à-vis the state) has existed since the founding ${ }^{22}$ its protection in the private workplace is a new and rising phenomenon. Indeed, until recently and in a manner consistent with much of the employment relationship generally, the law typically left such matters up to the employer and employee involved, with the at-will presumption firmly intact. ${ }^{23}$ To be sure, at-will exceptions were developed through both New Deal and Civil Rights era legislation, but these exceptions, unlike the standard conscience clause, were primarily designed to protect against "prejudice," or rather, employment decisions rendered on the basis of a particular status (e.g., union membership, race, gender) or act (e.g., the exercise of such status protections) largely unconnected to the performance of the job at issue. ${ }^{24}$

The modern conscience clause trend in private employment began in a limited, albeit politically charged, fashion shortly after the Supreme Court's decision in Roe v. Wade. ${ }^{25}$ Indeed, in response to Roe, which struck down most state law restrictions on a woman's right to choose to have an abortion, ${ }^{26}$ these "clauses" generally created a right of health care workers

21. Rob Stein, A Medical Crisis of Conscience, WaSH. POST, July 16, 2006, at A1 (describing the rise of conscience issues in the medical field as a "crisis").

22. See Nelson, supra note 9, at 143-45 (discussing the history and philosophical underpinnings of the Founders' recognition of public rights of conscience).

23. See Nader \& Hirsch, supra note 5, at 320 (discussing the tradition of the at-will presumption in the context of employee conscience prior to "the last few decades").

24. See Robert Post, Prejudicial Appearances: The Logic of American Antidiscrimination Laws, 88 CAL. L. REV. 1, 8 (2000) ("Antidiscrimination law seeks to neutralize widespread forms of prejudice that pervasively disadvantage persons based upon inaccurate judgments about their worth or capacities.").

25. See Katherine A. James, Note, Conflicts of Conscience, 45 WaShBURn L.J. 415, 417 (2006) ("In the field of medicine, conscience clauses first surfaced after Roe v. Wade.").

26. See Roe v. Wade, 410 U.S. 113, 164-65 (1973) (providing a summary of the court's holding in striking down relevant state abortion restrictions). 
to refuse to take part-a right which typically included protection from any discrimination by their employers, notwithstanding the at-will presumption. ${ }^{27}$ Although passage of such abortion-related laws met some opposition, particularly among the supporters of broad abortion rights, ${ }^{28}$ the response in the states to such proposals was overwhelmingly positive. ${ }^{29}$ Of course, there is also no doubt that given the narrowness of their subject matter, these abortion-based laws were likely more a political compromise between supporters and opponents of abortion than any broad-based enshrinement of employee conscience. ${ }^{30}$ In fact, one need only reflect on the relative paucity of case law on such clauses to support the conclusion that they were more the product of the politics of abortion, than the politics of the workplace. ${ }^{31}$ In any event, although some jurisdictions also included contraception, sterilization, euthanasia, or artificial insemination in such laws, abortion was largely where relevant conscience laws stood toward the end of last century. ${ }^{32}$

Fast-forward to the twenty-first century, and the conscience clause landscape is taking on a new and unprecedented shape. No longer limited to abortion, the current trend involves clauses that can cover virtually any health care decision whatsoever. The first of its kind was passed, somewhat ahead of its time, by Illinois in 1977 as part of its "Health Care Right of Conscience Act. ${ }^{33}$ This law protects against any discrimination in employment based on an employee's "conscientious refusal" to "participate in any way in any particular form of health care services contrary to his or her conscience." ${ }^{34}$ Such laws have since been passed in Washington (in $1995)^{35}$ and Mississippi (in 2004), ${ }^{36}$ and bills with similarly broad language

27. See Davis, supra note 8 , at 859-63 (summarizing conscience clause legislation in the labor context).

28. See Wardle, supra note 6, at 186 ("The greatest opposition to laws protecting the rights of conscience of health care institutions has come from advocates of absolute reproductive choice.").

29. See id. at 180 (noting the "widespread adoption of conscience clause statutes" on abortion).

30. See id. at 180-81 ("[T] conscience clauses was abortion, and most statutes responded to that specific concern, and no other.").

31. As of July 1, 2006, at least half of the state conscience clauses on abortion had never been cited in a law case. The relevant states include: Connecticut, Delaware, Hawaii, Idaho, Illinois, Indiana, Kansas, Maine, Mississippi, Missouri, Montana, Nebraska, Nevada, New Mexico, North Dakota, Oregon, Rhode Island, South Carolina, South Dakota, Tennessee, Utah, Virginia, Washington, West Virginia, and Wyoming. See infra note 234 (citing relevant state laws).

32. See Wardle, supra note 6, at 179-81 (discussing abortion-based conscience clause limits on statutes that had been adopted by 1993).

33. 745 Ill. Comp. Stat. ANN. 70/1 (West 2002).

34. Id. $70 / 5$.

35. WASH. REV. CODE ANN. $\S 70.47 .160$ (West 2002). 
have also been introduced in at least ten other states since the Mississippi statute took effect. ${ }^{37}$ In addition, similar statutes or bills have been adopted or proposed in the particularly controversial pharmacy arena in at least five other states in about the same period, though these are limited to providing pharmaceuticals. $^{38}$

Pertinently, the "wave" of state laws (or bills) just mentioned typically covers all "health care services," ${ }^{39}$ and not only abortion or other practices similar in their admitted degree of corresponding moral opposition in the wider culture. ${ }^{40}$ Furthermore, although such laws make reference to "conscience," most define that term in a virtually boundless fashion to include "religious, moral or ethical principles. ${ }^{.41}$ Finally, and perhaps most

36. Miss. CODE ANN. § 41-107-5 (West 2005).

37. See Pharmacist Conscience Clauses: Laws and Legislation, NAT'L CONF. OF STATE LEG., http://www.ncsl.org/programs/health/conscienceclauses.htm (last visited November $19,2006)$ [hereinafter NCSL REPORT] (summarizing pending or recently enacted conscience laws, including general bill proposals (i.e., those without procedure limits) from Alabama, Arkansas, Michigan, Missouri, Rhode Island, South Dakota, Texas, and Vermont). Other states with similar bills include New Jersey (A.B. 2016, 212th Leg., Reg. Sess. (N.J. 2006)) and West Virginia (S.B. 41, 77th Leg., Reg. Sess. (W. Va. 2006)).

38. See NCSL REPORT, supra note 37 (summarizing pending or recently enacted pharmacist bills, including general bills from California (S.B. 644, Reg. Sess. (Cal. 2005)), Minnesota (H.F. 2597, 84th Leg., 2005-06 Sess. (Minn. 2006)), Pennsylvania (H.B. 2217, Reg. Sess. (Pa. 2005)), and Tennessee (H.B. 1383, Reg. Sess. (Tenn. 2005)). Of these, only California's has been adopted. See CAL. Bus. \& PROF. CODE $\S 733$ (b)(3) (West Supp. 2006) (discussing when a pharmacist may decline to dispense a particular drug). In 2001, Georgia's State Board of Pharmacy also provided a general right not to fill prescriptions. See GA. COMP. R. \& REGS. § 480-5-.03 (2005) (describing Georgia's code of professional conduct for pharmacists in the state).

39. See, e.g., 745 ILl. Comp. Stat. ANn. 70/5 (West 2002) (covering "any particular form of health care services"); MISs. CODE ANN. $\S$ 41-107-5(3) (West 2005) (covering any "health care service"); WASH. REV. CODE ANN. $§ 70.47 .160(2)$ (a) (West 2002) (covering any "specific service"). See also proposed bills in Alabama (H.B. 609, Reg. Sess. (Ala. 2006)), Arkansas (S.B. 1141, 85th Gen. Assemb., Reg. Sess. (Ark. 2005)), Michigan (H.B. 4741, 2005-06 Sess. (Mich. 2005)), Missouri (H.B. 1539, 93rd Gen. Assemb., 2d Reg. Sess. (Mo. 2006)), New Jersey (A.B. 2016, 212th Leg., Reg. Sess. (N.J. 2006)), Rhode Island (H.B. 6793, Jan. Sess. (R.I. 2006)), South Dakota (H.B. 1184, 81 st Leg., Reg. Sess. (S.D. 2006)), Texas (S.B. 1016, 79th Leg., Reg. Sess. (Tex. 2005)), Vermont (H.B. 183, 2005-06 Reg. Sess. (Vt. 2005)), and West Virginia (S.B. 41, 77th Leg., Reg. Sess. (W. Va. 2006)), all of which cover any "health care service."

40. See Richard S. Myers, US Law and Conscientious Objection in Healthcare, in Cooperation, Complicity, \& Conscience: Problems in Healthcare, Science, LaW and Public POLICY 296, 314 (Helen Watt ed., 2005) (discussing the importance of "support for the underlying moral position ... in the broader society" in determining the likelihood of success for conscientious objections).

41. Miss. COdE ANN. § 41-107-3(h) (West 2005). See also 745 ILl. Comp. STAT. ANN. 70/3(e) (West 2002) (defining "conscience" broadly as a "sincerely held set of moral convictions"); WASH. REV. CODE ANN. $§ 70.47 .020$ (West 2002) (offering no definition of "conscience"). It should be noted further that all of the pending conscience bills use a variant of the "religious, moral, or ethical" definition. See supra note 39 (listing pending 
importantly from the perspective of an employer, although an inspiration for such statutes may have come from the analogous accommodation requirement in Title VII for religious practices, ${ }^{42}$ most of these new conscience laws lack both the "reasonable" and "undue hardship" qualifiers that are otherwise available to employers for the accommodation of religious practices under that federal law. ${ }^{43}$ As a result, a physician, for example, could refuse to prescribe, or to the contrary, insist on prescribing, birth control pills for an unmarried woman simply by citing his or her ethical principles. ${ }^{44}$ Or, perhaps more dramatically, a health care worker could refuse for moral reasons to remove a breathing tube from a patient or, conversely, to insert such a tube in the first place. ${ }^{45}$ To be sure, such dilemmas are not always easy, and there is no doubting that important interests are at stake, including both employee conscience and the interest of employers in providing the relevant, admittedly legal, service (not to mention the patients they both serve). And yet, the current trend is to provide an unqualified legal right to refuse-no questions asked, no dialogue required, and no opportunity for potentially deeper personal or institutional growth through a candid confrontation of values. ${ }^{46}$

In short, the foregoing conscience trend presents an unprecedented challenge to employers and to the at-will rule in the workplace. In light of the blanket nature of the relevant exemptions to perform, as well as the broad definitions of conscience that are offered both in existing law and in pending legislation, there is no question that employers face an increasingly serious challenge to how they choose to conduct their business. Indeed, as one commentator noted recently in the pharmaceutical context, "[ $t]$ his issue is the San Andreas Fault of our culture." ${ }^{, 47}$ At first glance, one might think this description a bit strong. And yet, when reflecting on the implications

legislation).

42. See 42 U.S.C. $\S 2000 \mathrm{e}(\mathrm{j})$ (2000) (describing the Title VII duty of employers to "reasonably accommodate" the religious practices of employees unless it would be an "undue hardship on the conduct of the employer's business").

43. The only limits on the rights of refusal in Illinois, Mississippi, and Washington are the rule in Illinois that one may not breach a contract or public funding rule and the rule in Washington of written notice to enrollees in the public health program by relevant providers. Of the pending bills, only Michigan requires written notice, and only Michigan and Texas provide exceptions for emergency situations. See supra note 39 (listing state laws and pending bills).

44. See generally Stein, supra note 21 , at $\mathrm{Al}$ (discussing conscience objections in the contraception context).

45. See id. at A6 (citing conscience objections in the "terminally ill" context).

46. See, e.g., MARY ANN GLENDON, Rights TALK 14 (1991) ("Our rights talk, in its absoluteness, promotes unrealistic expectations, heightens social conflict, and inhibits dialogue that might lead toward consensus, accommodation, or at least the discovery of common ground.").

47. Stein, supra note 21, at A6 (quoting Gene Rudd of the Christian Medical \& Dental Associations). 
of such broad rights of refusal, a resulting conflict between employers and employees seems almost inevitable. Of course, one might argue, and rather correctly, that this is simply the natural consequence of the law's resolving a conflict that otherwise exists between the two parties. However, this still begs the question as to whether or not the law, as opposed to frank dialogue or free competition, is the proper mechanism for such a resolution in the first place. Thus, it is to that very question that the remainder of this article is devoted.

\section{II. “AT WILL” AUTHORITY: AN EMPLOYER's FIRST (AND LAST) RESORT}

Most scholars mark the articulation of "Wood's Rule" in 1877 as the official birth of the at-will presumption in American law. ${ }^{48}$ This rule, which is named after its author and the chief at-will proponent of the era, New York lawyer Horace Gray Wood, states, "[w]ith us the rule is inflexible, that a general or indefinite hiring is prima facie a hiring at will." Interestingly, Wood's Rule was a departure from the English law tradition that "used presumptions of long-term hiring [typically a year] and required reasonable notice of termination." To the contrary, Wood's Rule held that "if the servant seeks to make it out a yearly hiring, the burden is upon him to establish it by proof." T1 Though many legal historians doubt the depth of then-existing case or other legal support for Wood's Rule, ${ }^{52}$ there is no question its opposition to the English presumption of one-year hiring captured the laissez-faire spirit of both the legal and business cultures of the time $\mathrm{s}^{53}$ - a theme that, although eroded to a degree by various judicial and statutory exceptions, remains today. ${ }^{54}$

48. See Feinman, supra note 3, at 126-27 (describing the development and impact of "Wood's Rule").

49. Id. at 126 (quoting HoraCE GRAY WOOD, MASTER AND SERVANT $\S 134$ (1877)).

50. Id. at 118-19. See also id. at 120 (analyzing the one-year contract presumption in English law).

51. Id. at 126 (quoting WoOD, supra note 49 , at $\S 134$ ).

52. See Mary Ann Glendon \& Edward R. Lev, Changes in the Bonding of the Employment Relationship: An Essay on the New Property, 20 B.C. L. REV. 457, 458 (1979) (positing that the at-will presumption "was first asserted without analysis or judicial support by H. G. Wood in his 1877 treatise on master and servant law"). But see generally Deborah A. Ballam, The Traditional View on the Origins of the Employment-At-Will Doctrine: Myth or Reality?, 33 AM. BUS. L.J. 1 (1995) (asserting that, contrary to the claims of many, the atwill doctrine was fairly prevalent in America (at least for "free laborers") before Wood's treatise).

53. See Glendon \& Lev, supra note 52, at 458 (stating that Wood's Rule "was highly compatible with prevailing laissez-faire notions and was readily accepted by the courts").

54. See Amy M. Carlson, Comment, States Are Eroding At-Will Employment Doctrines: Will Pennsylvania Join The Crowd?, 42 DuQ. L. REv. 511, 513-14 (2004) ("Though . . . exceptions have eroded the at-will employment doctrine to varying degrees among the nation's jurisdictions, the doctrine still endures in the United States today. Only 
The one-year presumption in the English law, as observed by Blackstone in 1765 , was rooted "upon a principle of natural equity, that the servant shall serve, and the master maintain him, throughout all the revolutions of the respective seasons; as well when there is work to be done, as when there is not." "Is Implicit in such a "principle," of course, were presumptions of both the agricultural (i.e., seasonal) and domestic (i.e., of a household) ${ }^{56}$ nature of most pre-Industrial Revolution work. ${ }^{57}$ To be sure, such work involves a deeper master-servant bond than typically found in a factory, with agriculture demanding mutual aid through a fixed plant-grow-harvest-rest cycle ${ }^{58}$ and household work naturally requiring a high level of trust, given its personal nature. ${ }^{59}$ Indeed, Blackstone himself lists master and servant, along with marriage and parenthood, as " $[t]$ he three great relations in private life." ${ }^{, 60}$ Historically, there is no question the annual presumption went beyond the farm and homestead. ${ }^{61}$ Yet there is also no doubt it denoted a view of work tied to feudal ideas of lord, loyalty, and land that had clearly faded by the time of Wood. ${ }^{62}$

one state [Montana], through legislative measures, has completely eliminated the presumption of at-will employment.").

55. William Blackstone, 1 Commentaries *413. See also Feinman, supra note 3, at 120 (quoting the same excerpt from Blackstone).

56. See Black's LaW Dictionary 484 (6th ed. 1990) (describing the "household" connection in many legal terms that contain the "domestic" descriptor).

57. On pre-industrial labor, "[d]uring the period from 1500 to 1800 , almost everywhere in Europe more than half the working population was still employed in agriculture ... [and] even where pre-industrial life was no longer based on agriculture, it remained a very important factor." 5 THE CAMBRIDGE ECONOMIC HiSTORY: THE ECONOMIC ORIGINS OF EARLY MODERN EUROPE 45 (E.E. Rich \& C.H. Wilson eds., 1977). In addition to agricultural and domestic influences, scholars have also noted the impact of the English Poor Laws (which otherwise imposed responsibility on the community at large, if not employers, to support the poor) and the Statute of Labourers (which imposed a more general obligation to work) as additional factors in the one-year presumption's formulation. See Ballam, supra note 52, at 2 ("The annual hiring rule minimized the community's responsibility for poor relief by requiring the employer to maintain employees for a year at a time."); Feinman, supra note 3, at 120 (discussing the influence of the Poor Laws and Statute of Labourers on the one-year rule).

58. See Ballam, supra note 52, at 2 (discussing the mutual interests of agricultural employers and employees served by the presumption of one-year employment under English law).

59. See BLACKSTONE, supra note 55, at*413-15 (distinguishing between domestics (to whom the one-year presumption applies) and other servants in that the former "live intra moenia [i.e., inside the walls], as part of the family" (id. at *414)). See also Jay M. Feinman, The Development of the Employment-at-Will Rule Revisited, 23 ARIZ. ST. L.J. 733, 734 (1991) (discussing the "personal, often even familial" nature of a traditional masterservant relationship).

60. BLACKSTONE, supra note 55 , at $* 410$.

61. See Feinman, supra note 3, at 120 ("The [English law] presumption that an indefinite hiring was a hiring for a year extended to all classes of servants.").

62. See Glendon \& Lev, supra note 52, at 458 (stating that the at-will rule helped the 
In general, the at-will presumption in the United States, whether adopted before or after Horace Wood, flourished largely in the context of the "new economy" of the mid to late-nineteenth century. ${ }^{63}$ In both theory and practice, the "American Experience" of that era differed from its English counterpart. Lamentably, many of the differences in the colonial and antebellum periods arose from the use both of slave labor, which naturally disregarded presumptions of term length, and indentured servitude, which typically had a fixed term and, thus, had no need for any length of service presumptions. ${ }^{64}$ Beyond such uglier elements, however, the rise of mass manufacturing, together with the prominence of fairly mobile immigrant workers (particularly after 1860) and the prominent idealism of free enterprise all pointed to a certain degree of liberty from both the constraints and protections of the feudal approach. ${ }^{65}$ In this regard, "[a] belief in rugged individualism, laissez-faire in contractual relations, and survival of the fittest dominated late-nineteenth century thought," and, thus, the at-will employment presumption can be seen more as a natural corollary of such thinking than as an independent rule of contractual construction.

Historically, the at-will presumption has been supported, in whole or in part, by principles of freedom of contract, ${ }^{67}$ freedom of enterprise, ${ }^{68}$

master-servant relationship to "escape[] the conceptual framework of the law of domestic relations, where it had been dominated by the ideas of protection and loyalty that had characterized the still older relationship of lord and vassal").

63. See Ballam, supra note 6, at 654 ("Courts first explicitly began discussing the employment-at-will rule in the post-Civil War period, the height of the development of the new industrial economy, although evidence suggests that in fact it had been a long-standing policy.").

64. See Ballam, supra note 52, at 9 (discussing the inapplicability of the one-year presumption on slavery and indentured servitude in early America).

65. See Jonathan Hughes \& Louis P. Cain, American Economic History 409-13 (5th ed. 1998) (discussing the nature of the American workforce in the mid to late nineteenth century, which emphasized its "pioneer and frontier traditions" over any "extraordinary concern for working employees" as a group). See also JAMES A. HENRIETTA, THE ORIGINS OF AMERICAN CAPITALISM 271-72 (1991) (arguing that, by the end of the eighteenth century, "[t]he paternalistic labor system ... had given way to a more flexible and transient pattern of work relations[,] . . [ [which] aided entrepreneurs, who could now respond more quickly and efficiently to changing market conditions").

66. Ballam, supra note 6, at 656. See also Carlson, supra note 54, at 513 ("Many legal scholars have suggested the at-will employment doctrine was so widely accepted because it fit with the prevailing laissez-faire economic climate of the era.").

67. See Carlson, supra note 54, at 513 ("[T] he at-will employment doctrine embraces freedom of contract principles, which played a key role in developing the free enterprise system.").

68. See Cheryl S. Massingale, At-Will Employment: Going, Going . ., 24 U. RICH. L. REV. 187, 188-89 (1990) ("The principle underlying the right of the employer to terminate at-will is, in fact, based more on freedom of enterprise than freedom of contract.") (citation omitted). 
property rights, ${ }^{69}$ economic or market efficiencies, ${ }^{70}$ and judicial economy, ${ }^{71}$ all of which typically concern economic or political, rather than personal, rights. As such, it is no surprise that the presumption enjoyed such broad support in the nineteenth century. According to legal historian Lawrence Friedman, the market at that time "guaranteed nothing to any particular individual, whose fate depended on his own exertions. ... At the heart of it was the concept of the self-made man." 72 At the present, there is no question that, from whatever source, supports for at-will authority have been challenged in varying degrees by way of statutory or judicial exceptions begun in the twentieth century (e.g., anti-discrimination laws, claims for wrongful discharge) that tend to focus on dependent employee rights rather than market freedoms or prerogatives. ${ }^{73}$ However, as studied in much greater detail in Part IV below, the power of such supports should not be underestimated, particularly when assessing such exceptions in a conscience arena that naturally reaches beyond the prejudicial and non-jobrelated status concerns of relevant anti-discrimination laws and their like and into the performance (or not) of actual job tasks.

To be sure, the twentieth century did much to undercut the at-will presumption. In this regard, "[d]ating [largely] from the $1960 \mathrm{~s}, \ldots$ when government was focusing more of its regulations on quality of life and individual liberty issues, many exceptions to the [at-will] doctrine's

69. See Keith N. Hylton, A Theory of Minimum Contract Terms, With Implications for Labor Law, 74 TEX. L. REv. 1741, 1752 (1996) (discussing support for the at-will presumption through private property theory in that " $[t]$ he at-will doctrine recognizes the employer's ownership of a job slot as a form of private property: just as the owner of a parcel of land could exclude others from that parcel for any reason whatsoever, so too could an employer exclude a worker from a job slot").

70. See Andrew P. Morriss, Bad Data, Bad Economics, and Bad Policy: Time to Fire Wrongful Discharge Law, 74 TEx. L. REV. 1901, 1902 (1996) (discussing the market efficiencies of the at-will presumption in serving "the needs of both employers and employees").

71. See id. at 1933-34 (discussing the judicial economy rationale for the at-will presumption).

72. Lawrence M. Friedman, The Republic of Choice: Law, Authority, and Culture 31 (1990). Professor Deborah Ballam also draws on Professor Friedman in arguing that the shift from the nineteenth to twentieth century on the at-will rule was due largely to a shift in the cultural notion of the individual from self-control to self-expression. See Ballam, supra note 6 , at $682-85$. In the nineteenth century, "[ $[$ ] $]$ he law's role was to serve as the glue that preserved this 'free market' society where individuals could control their own destiny and advance [or not] through individual effort and discipline." Id. at 683 (citing FrIEDMAN, supra at 31). As such, "[b]oth worker and boss were individuals who had full freedom of choice." FRIEDMAN, supra, at 83.

73. See, e.g., Rachel Geman, Safeguarding Employee Rights in a Post-Union World: A New Conception of Employee Communities, 30 Colum. J.L. \& SoC. Probs. 369, 385 (1997) ("[C]urrent employment law focuses on individual employees."). See also FRIEDMAN, supra note 72 , at 106 ("A striking feature of contemporary law is the tendency to strengthen job .. . security."). 
applicability began developing from both statutory and common law sources." ${ }^{, 74}$ On the statutory side, the most obvious exception is Title VII, which makes it illegal for covered employers (generally those with fifteen or more workers) ${ }^{75}$ to "discriminate against any individual with respect to .

terms, conditions, or privileges of employment, because of such individual's race, color, religion, sex, or national origin." ${ }^{, 76}$ Indeed, this non-discrimination provision, which is mirrored in almost every state (usually for smaller employers), ${ }^{77}$ is undeniably the most significant statutory exception to the at-will rule. Others include, on the federal level, the following: the earlier National Labor Relations Act of 1935 and its group action protections (with collective bargaining agreements often to follow) ${ }^{78}$ the age protections of the Age Discrimination in Employment Act of $1967 ;^{79}$ the disability coverage of the Americans with Disabilities Act of $1990{ }^{80}$ the non-retaliation rules of the Fair Labor Standards Act of $1938{ }^{81}$ Occupational Safety and Health Act of $1970,{ }^{82}$ Employee Retirement Income Security Act of $1974,{ }^{83}$ and Family and Medical Leave Act of $1993 ;^{84}$ and, of course, the narrow abortion-based federal "conscience clause" (known as the Church Amendment). ${ }^{85}$ A host of laws in similar areas (e.g., age or disability protection, wage payment nonretaliation, "whistleblower" coverage) and even in different ones (e.g., family status, sexual orientation, or smoker non-discrimination) exists on the state and local levels as well. ${ }^{86}$

74. Ballam, supra note 6 , at 654 .

75. See 42 U.S.C. $\$ 2000$ e(b) (2000) (defining “employer" for purposes of Title VII).

76. Id. $\S 2000 \mathrm{e}-2(\mathrm{a})(1)$.

77. See LeX K. LARSON, EMPloyment Discrimination $\S 114.01$ (2d ed. 2003) ("Enforceable state laws designed to prohibit employment discrimination in private employment .... are found in forty-six states, [with Alabama, Mississippi, Georgia (public employees only), and North Carolina (policy statement only) being the exceptions], the District of Columbia, Puerto Rico, and the Virgin Islands."). See also id. §§ 114.02$114.02[2]$ (noting that state discrimination laws largely "mirror Title VII and other major federal statutes," yet generally require fewer than the fifteen employees needed for Title VII coverage).

78. 29 U.S.C. $\S 151(2000)$.

79. Id. $\S 621$.

80. 42 U.S.C. $\S 12101(2000)$.

81. 29 U.S.C. $\& 215(a)(3)(2000)$.

82. Id. $\S 660(\mathrm{c})$.

83. Id. $\S 1140$.

84. Id. $\S 2615$.

85. 42 U.S.C. \& 300a-7 (2000).

86. For a discussion of state age discrimination laws, see Howard C. EGLIT, AGE DISCRIMINATION $\S 11.27$ (2005) (noting that "great majority of states" and "some local governmental bodies" have age protections); for disability laws, see JOHN J. COLEMAN, III, DISABILITY DISCRIMINATION IN EMPLOYMENT $\S 8.1$ (2005) (discussing the forty-eight states that protect disabled workers in private work); for wage payment or other statutory-based retaliation, such as worker's compensation, jury duty, military service, see RSM 
Turning to the common law, many state courts have developed exceptions to the at-will presumption that go beyond the otherwise applicable statutory provisions on discrimination or retaliation. In general, "the courts have recognized exceptions to the at-will rule based on these premises: implied contracts (including employer handbooks and manuals, oral representations, and promissory estoppel), covenants of good faith and fair dealing, and public policy." ${ }^{, 87}$ Tort concepts, such as intentional infliction of emotional distress, interference with contractual relations, and defamation, have also played a role - at least in the manner, if not fact, of discharge ${ }^{88}$ Presently, at least the following number of states recognize these theories in one degree or another: implied contract (45) ${ }^{89}$ good faith and fair dealing (9), ${ }^{90}$ violation of "public policy" (40), ${ }^{91}$ intentional infliction of emotional distress (33), ${ }^{92}$ interference with contracts (31), ${ }^{93}$ and defamation (34). ${ }^{94}$ Thus, it can be safely said that at least forty-five states have some form of "wrongful discharge" exception to the at-will presumption (including Montana's unique "cause" statute), ${ }^{95}$ and,

MCGladrey, InC., Mandated Benefits: 2005 Compliance Guide Ex. 17.2 (2005) (providing a state law chart on "statutory restrictions on discharging employees"); for worker safety and related "whistleblower" rules, see JOHN E. BUCKLEY \& DWIGHT D. Wilkerson, 2006 State by STATE Guide to WorkPlace Safety Regulation $\S 9.02$, tbl.9-2 (2005) (safety-based retaliation protections); for marital or sexual orientation provisions, see LARSON, supra note 77, at $\$ 114.02[3]$ (marital status laws in twenty states and District of Columbia and sexual orientation laws in thirteen states and District of Columbia); and, for smoker protections, see $i d$. ("Twenty-seven states and the District of Columbia prohibit employers from discriminating against persons because the individual is a smoker or nonsmoker."). As noted above, Montana is the only state that has a general wrongful discharge statute. See MONT. CODE ANN. § 39-2-901 (2005).

87. John F. Buckley, IV \& Ronald M. Green, 2006 State by State Guide to HUMAN RESOURCES LAW $§ 5.01$ [B] (2006).

88. See id. $\S 5.03$ (describing "causes of action for wrongful discharge based on tort theories").

89. See id. at tbl.5-1 (listing states' recognition of implied contract). The approximate number of "implied contract" states have expressly recognized such "contracts" are as follows: handbooks/manuals (41), oral representation (32), and promissory estoppel grounds (26). See id. (listing states).

90. See id. (listing states' recognition of a "covenant of good faith and fair dealing").

91. See id. at tbl.5-3 (listing states' recognition of a "violation of public policy" as the basis for a wrongful discharge claim). See also id. at tbl.5-4 (sub-classifying public policy theories in the states).

92. See id. at tbl.5-3 (listing states' recognition of an "intentional infliction of emotional distress" cause of action in the employment termination context).

93. See id. (listing states' recognition of "interference with contractual relations" in employment action).

94. See id. (listing states' recognition of defamation in the employment termination arena).

95. See RSM MCGLadREY, INC., supra note 86, at ex. 17.3 (providing state chart of "remedies for wrongful discharge" and indicating, by reference, that only Alabama, Arizona, Georgia, Rhode Island, Vermont, and the District of Columbia lack "a court- 
consequently, it is far from its iron-clad status of the nineteenth century.

Notwithstanding the foregoing exceptions that have eroded the at-will rule in the past several decades, however, it remains the presumption in all states except Montana. ${ }^{96}$ Indeed, although subject to these exceptions, "[a]s many as 75 million workers in this country are [still] considered to be atwill employees, subject to discharge at any time and unprotected by specific laws or collective bargaining agreements." 97 As one critic put it recently, "even with the presence of numerous exceptions, employment at will leaves American workers some of the most vulnerable to arbitrary discharge in the Western world." 98 Furthermore, even considering the exceptions, some do nothing more than expand evidence for an actual (albeit implied) contract, others simply require good faith, not cause (e.g., good faith and fair dealing), and still others merely transfer otherwise operative tort notions into the workplace (e.g., infliction of emotional distress, contract interference, defamation). Perhaps the broadest exceptions come from the federal or state discrimination laws and various "public policy" notions in many states, yet even those restrict employer discretion only in prejudicial or other circumstances largely unrelated to actual job performance by the worker at issue. ${ }^{99}$ Therefore, although at-

created remedy for wrongful discharge").

96. See Bradley T. Ewing et al., The Employment Effects of a "Good Cause" Discharge Standard in Montana, 59 IndUS. \& LAB. REL. REV. 17, 17 (2005) (noting that by a 1987 statute, "Montana became the only state to adopt a 'good cause' standard for discharge of employees with contracts of unspecified duration"). See also Arthur S. Leonard, A New Common Law of Employment Termination, 66 N.C. L. REV. 631, 636 (1988) ("All of the decisions upholding a cause of action do so within the framework of an exception to an underlying at will rule.").

97. BUCKLEY \& GREEN, supra note 87 , at $\S 5.01$.

98. Robert C. Bird, Employment as a Relational Contract, 8 U. PA. J. LAB. \& EMP. L. 149,160 (2005).

99. As to Title VII, the Supreme Court noted in Griggs v. Duke Power Co., 401 U.S. 424,431 (1971), that " $[w]$ hat is required by Congress is the removal of artificial, arbitrary, and unnecessary barriers to employment when the barriers operate invidiously to discriminate on the basis of racial or other impermissible classification." Similarly, with respect to "public policy" exceptions to the at-will presumption, it is not the individual job performance (or the lack thereof), but rather "the public interest" typically reflected elsewhere in law. See Ballam, supra note 6, at 664 ("While the states that adopted the wrongful discharge based on public policy doctrine differed in their approach, all of them, regardless of whether they chose the narrow or broad approach, required a clear link to a definite source of law that either would be violated or definitely undermined to satisfy the public policy requirement."); Massingale, supra note 68, at 191 ("In most cases, the courts have required a clear mandate that a particular policy is necessary to protect the public interest"). See also Andre D. Bouffard, Emerging Protection against Retaliatory Discharge: A Public Policy Exception to the Employment At-Will Doctrine in Maine, 38 ME. L. REv. 67, 80 (1986) (noting that the "public interest" supporting the "public policy" exception to the at-will rule is "generally unrelated to obligations created by the parties through their contract"). 
will exceptions do exist, none (save in Montana) have risen to the level of a firm contractual presumption (one year or otherwise) or blanket "for cause only" discharge standard. Consequently, it would be a serious mistake to interpret the passage of a broad conscience accommodation law-which, by its very nature, would directly involve the performance of one's job-as simply one more in a consistent line of legal conditions on employer authority.

\section{CONSCIENCE AT WORK: Faith AND Morals In THE MARKETPlace}

Having explored the history and current state of the at-will presumption, including exceptions thereto, let us now study the other side of this article's coin-conscience. In Part IV, we will explore how the atwill rule and conscience work together (or not), but first it is critical to understand how conscience is considered at all, both generally and at work. There is no doubt that "freedom of conscience" is a concept that has been highly valued since the founding of our nation. ${ }^{100}$ And yet, what does that phrase mean? What are its constitutional and statutory parameters? What is its legal status in the workplace? Answers to such questions are not only intriguing in themselves and important in our understanding of conscience in the law generally, but they are also indispensable in framing the presumption-conscience dilemma that lies at the heart of this article.

\section{A. The Meaning of Conscience in American Law and Culture Generally}

In his famous 1785 Memorial and Remonstrance against Religious Assessments, James Madison opined: "[t]he Religion then of every man must be left to the conviction and conscience of every man; and it is the right of every man to exercise it as these may dictate. This right is in its nature an unalienable right." Madison called a "gift of nature," 102 certainly pre-dates the founding of the United States. As the Jesuit priest Richard J. Regan once noted, "[n]o culture without some idea of moral conscience has yet been discovered." 103 In the Judeo-Christian tradition, discourse on conscience runs from the Genesis lesson on the proper (and improper) use of free will, to Saint

100. See generally Michael W. McConnell, The Origins and Historical Understanding of Free Exercise of Religion, 103 HARV. L. REV. 1409 (1990) (discussing the conscience origins of the First Amendment's Free Exercise Clause, while distinguishing between religious and secular conscience in its adoption).

101. JAMES MADISON, Memorial and Remonstrance against Religious Assessments, in JAMES MADISON: WRITINGS 30 (J. Rakove ed., 1999) (1785).

102. Id. at 35.

103. Richard J. Regan, Private Conscience and Public law: The american EXPERIENCE 207 (1972). 
Paul's exhortation of a "pure heart," to Saint Thomas Aquinas' (and later, John Henry Newman's) ideal of "right judgment," to Martin Luther's protests against Rome, and up through Martin Luther King's civil rights cause. ${ }^{104} \mathrm{~A}$ similar focus can be seen in more secular thinkers, from Socrates' inner "voice," to John Locke's proposal of self-interested tolerance, to Immanuel Kant's concept of "good will," and, certainly, to that likely hero of American civil disobedience, Henry David Thoreau. ${ }^{105}$ Among the Eastern religions and thinkers, the Qur'an speaks of " $[t]$ he soul and how it was integrated [a]nd given the faculty of knowing what is disruptive and what is intrinsic to it," 106 and, though more muted and linked to family or caste than individual conviction, even Confucianism, Buddhism, and Hinduism note the importance of personal understandings of the good. ${ }^{107}$

Notwithstanding the potentially global reach of the concept, the use of conscience in American legal culture is predictably Christian, or at least Lockean, in its origins. ${ }^{108}$ The word conscience comes from the Latin root

104. See id. at 207-31 (discussing the importance of conscience as an ideal in the JudeoChristian tradition beginning with the first book of the Old Testament). See also George Cardinal Pell, The Inconvenient Conscience, FIRST THINGS, May 2005, at 22-26 (describing Catholic thinking on conscience, particularly that of John Henry Newman and Pope John Paul II).

105. See REGAN, supra note 103, at 211-12, 219-29 (surveying Western thinkers on their various notions of conscience, including Socrates, Locke, Kant, and Thoreau).

106. Al-QUR'ĀN, 91:7-8 (Ahmed Ali trans., Akrash Publishing 1984). See also David LITTLE ET AL., Human Rights and the World's Religions: Christianity, Islam, and Religious Liberty, in Religlous Diversity AND HuMAN Rights 232 (Irene Bloom et al. eds., 1996) [hereinafter, BLOOM] ("No reader of the Qur'an can possibly escape the message, repeated again and again, that faith and unfaith, belief and unbelief, are matters which are properly the concern of God, not of any human authority.").

107. See, e.g., IRENE BloOM, Confucian Perspectives on the Individual and the Collectivity, in BLOOM, supra note 106, at 129-31 (noting the Confucian idea of a "moral capacity" that is "present in every human being"); ROBERT A.F. THURMAN, Human Rights and Human Responsibilities: Buddhist Views on Individualism and Altruism, in BLOOM, supra note 106, at 94-98 (discussing the Buddhist concept of "social individualism" and ethics); Mark JUergenSMeYer, Hindu Nationalism and Human Rights, in BloOM, supra note 106, at 244-47 (commenting on the range of "Hindu values," including dharma, or moral duty, which although connected to social role, includes a host of values, including the "force of truth" extolled by Mohandas Gandhi). See also O'Callaghan, supra note 18, at 615 (arguing in the support of conscience as a constitutional right that "even over the widest gaps of religious diversity there is still a rough consensus among religions on wide areas of morality and civic life, including respect for families, public order, pursuit of the common good ... [such that] the common elements of morality of most religions are more remarkable than the differences").

108. See McConnell, supra note 100, at 1430-55 (describing the influence on the framers of both Locke's "toleration" and Christian evangelicalism. See id. at 1431 ("Locke's ideas . . . are an indispensable part of the intellectual backdrop for the framing of the free exercise clause."); id. at 1437 ("To determine the meaning of the religion clauses, it is necessary to see them through the eyes of their proponents, most of whom were members of the most 
conscientia (from cum (meaning "with") and scire (meaning "to know")), ${ }^{109}$ which has two relevant alternative definitions of "the holding of knowledge in common" or "an inward perception of the rectitude or otherwise of one's actions." $"$ Absolute agreement on the meaning of the term would most likely escape the world's great religions and thinkers just noted, although the notion of a "moral sense" probably comes the closest, ${ }^{111}$ with such a definition matching particularly well from the prevailing perspectives in our country's founding generation. ${ }^{112}$ Indeed, whether out of a supposed Christian magnanimity or a Lockean self-interest (either political or religious), the signers to the religion provisions of the First Amendment were, at a minimum, united in their desire to protect "liberty of conscience." $" 113$

For better or worse, the concept of conscience has "evolved" since the founding. Reflected in certain prominent thinkers from John Stuart Mill to Max Weber to Michael Sandel, ${ }^{14}$ it has proceeded from the rooted,

fervent and evangelical denominations in the nation."). See also BENJAMIN HART, FAITH AND FREEDOM: THE CHRISTIAN ROOTS OF AMERICAN LIBERTY 343 (1988) ("[F]reedom of conscience [at America's founding] was hardly an Enlightenment or humanist notion; it is a Christian principle applied to politics."); ALEXIS DE TOCQUEVILLE, DEMOCRACY IN AMERICA 293 (J.P. Mayer ed., 1969) (1835) ("For the Americans the ideas of Christianity and liberty are so completely mingled that it is almost impossible to get them to conceive of one without the other."); Douglas W. Kmiec, Natural-Law Originalism-Or Why Justice Scalia (Almost) Gets It Right, 20 HARV. J.L. \& PUB. PoL'y 627, 641 \& n.57 (1997) (describing the "overwhelmingly Christian nature" of the founders, where "98.4 percent [were] Protestant, 1.4 percent [were] Roman Catholic, and three-twentieths of one percent [were] Jewish") (citing HART, supra, at 337).

109. Webster's New Collegiate Dictionary 240 (1975) (providing both the definition and etymology of the word "conscience").

110. OXFORD LATIN DicTIONARY 411 (1982).

111. See id. (including "moral sense" as a clarifying definition of the Latin word conscientia).

112. See McConnell, supra note 100 , at 1493 (providing various definitions of conscience in the founding era, such as Noah Webster's 1807 "natural knowledge, or the faculty that decides on the right or wrong of actions in regards to one's self," James Buchanan's 1757 "testimony of one's mind," and Samuel Johnson's 1805 "knowledge or faculty by which we judge of the goodness or wickedness of ourselves") (internal citations omitted).

113. HART, supra note 108 , at 343 . See also id. at 340 ("There is no doubt that the majority opinion in America during the late 18th century was that separation of church and state was essential to preserving religious freedom.").

114. On the impact of John Stuart Mill on notions of conscience, see Commonwealth v. Bonadio, 415 A.2d 47, 50-51 (Pa. 1980) (applying Mill's philosophy in the sexual freedom context); for Max Weber, see FRIEDMAN, supra note 72, at 23 (discussing Weber's thought on the rise of the individual in the modern age); and for Michael Sandel, see Rodney K. Smith, Conscience, Coercion and the Establishment of Religion: The Beginning of an End to the Wandering of a Wayward Judiciary?, 43 CASE W. RES. L. REV. 917, 940-43 (1993) (noting Sandel's invocation of "individual choice" as the "predominant justification for a right of conscience" in the constitutional context). 
objective idea above to "absolute freedom of opinion and sentiment on all subjects, practical or speculative, scientific, moral, or theological." 115 As George Cardinal Pell put it recently, "[w]here the world once valued autonomy as the recognition that we are bound by moral laws, it now understands [it] as the existential liberty to compose our lives, and even reality, for ourselves." 116 Thus, "[t]he central concepts of modern legal culture are choice, consent, freedom, and individual rights. These are old terms, but what they mean in the [modern era] is startlingly different from what they meant to Jefferson or Locke." 17 In this, the oft-cited, though admittedly broad, phrase from Planned Parenthood of Southeastern Pennsylvania v. Casey comes to mind: "At the heart of liberty is the right to define one's own concept of existence, of meaning, of the universe, and of the mystery of human life." 118

The general agreement concerning the objective nature of conscience described in the penultimate paragraph, however, need not automatically give way to the relativism reflected in the last, particularly when considering the context of conscience clauses in private employment. First, it should be noted that the relevant language in the case of the federal constitution (and, as described in detail below, Title VII and its state counterparts) still only covers "religion," and not conscience generally. ${ }^{119}$ While some view this as a distinction without a difference, ${ }^{120}$ there is no doubt that the words expressly address only religion, and not other forms of conscience, ${ }^{121}$ thus avoiding confusion as to any larger meaning. Second, even to the extent that the post-modern understanding of conscience has overcome the historical in favoring personal rights over universal truth, ${ }^{122}$ its use in the broader legal culture, at least up to this point, still retains some claim to objectivity. ${ }^{123}$ Third, and as also discussed below, even

115. JOHN STUART MiLl, ON LIBERTY 11 (Elizabeth Rapaport ed., 1978) (1860).

116. Pell, supra note 104, at 25.

117. FRIEDMAN, supra note 72 , at 36.

118. Planned Parenthood of Se. Pa. v. Casey, 505 U.S. 833, 851 (1992).

119. See U.S. CONST. amend. I (providing that, "Congress shall make no law respecting an establishment of religion, or prohibiting the free exercise thereof') (emphasis added).

120. See, e.g., Steven D. Smith, What Does Religion Have to Do with Freedom of Conscience?, 76 U. COLO. L. REV. 911,911 (2005) ("Although 'freedom of conscience' is nowhere expressly mentioned in the text of the Constitution, its absence from the document is probably a historical accident.").

121. See, e.g., McConnell, supra note 100, at 1489 ("The choice of the words 'free exercise of religion' in lieu of 'rights of conscience' is . . of utmost importance.").

122. See Pell, supra note 104, at 23-24 (discussing the contrast between modern conceptions of "conscience" as "primarily a mark of individual autonomy" and the traditional understanding, as exemplified by the writings of John Henry Newman, which, even if not particularly Christian, contains at least some element of "moral truth" or "objective moral law").

123. For example, even in the otherwise broad "conscientious objector" context of military service, a "merely personal code" is left unrecognized by the relevant statute and 
where such objectivity has departed (or at least been stretched), such instances, unlike the conscience clause trend, are limited almost entirely to public (i.e., vis-à-vis the state) rather than private rights ${ }^{124}$ - a context which, after all, was the one in which Madison penned his Remonstrance in the first place. ${ }^{125}$

Based on the foregoing exploration of conscience in law and culture generally, we are presented with a recurring reference to the good, which, even if to varying degrees, is distinct from a pure subjective preference. ${ }^{126}$ Indeed, philosophically speaking, only the strictest nihilist would suggest that the cultural understanding of conscience is devoid of objective content. ${ }^{127}$ And yet, in the context at issue-private employment in the modern era-such objectivity is increasingly ignored. ${ }^{128}$ To wit, the lowest common denominator of choice, whether by accident or design, effectively replaces conscience in a manner that goes beyond simply resisting state power and into mediating matters of private, personal opinion. ${ }^{129}$ Perhaps it should be obvious that given the rise of subjectivity in the post-modern meaning of conscience that related legal rules would be similarly imprecise. ${ }^{130}$ And yet, even if such relativity were otherwise acceptable in a modern, pluralistic society at large or even, for the matter, in the context of one's public rights, its use in the private workplace presents an unprecedented, and potentially untenable, tension.

\section{B. Conscience and First (Amendment) Principles}

Whether or not the relevant separation is philosophically sound, and for whatever reason, ${ }^{131}$ there is no question that the drafters of the First

case law. See United States v. Seeger, 380 U.S. 163, 185-86 (1965) (discussing conscientious objection in the military draft context).

124. See, e.g., Lawrence v. Texas, 539 U.S. 558, $573-74$ (2003) (describing rights to personal "autonomy" in the context of the public regulation of certain "personal decisions").

125. See Vischer, note 10 , at 84 (distinguishing between private and public impositions on conscience).

126. Supra notes 104-107.

127. See John Finnis, Retribution: Punishment's Formative Aim, 44 AM. J. JuRIs. 91, 93 (1999) (discussing Friedrich Nietzsche's conception of conscience as a "deep sickness to which man was obliged to succumb" by social force) (quoting FRIEDRICH NIETZSCHE, ON THE GENEALOGY OF MORALS (D. Smith trans., 1996) (1887)).

128. See Wardle, supra note 6, at 196 (noting the open-ended grounds of "conscience" in relevant statutes).

129. See MYERS, supra note 40, at 296-97 (on the dominance of the concepts of "choice" and "personal autonomy" in the modern "public policy debates" relating to "rights of conscience in health care").

130. See FRIEDMAN, supra note 72 , at 35 (observing that " $[\mathrm{t}]$ he new variety of individualism" in the twentieth century culture at large "naturally seeps into legal culture as well").

131. See McConnell, supra note 100, at 1486 (discussing the lack of "recorded debate or 
Amendment chose to protect religious rather than a more general, and arguably broader, notion of conscience. ${ }^{132}$ The relevant language is as follows: "Congress shall make no law respecting an establishment of religion, or prohibiting the free exercise thereof." McConnell has observed, in adopting the final version of this text, the United States Senate deleted the phrase "rights of conscience," which was included in an earlier version in the House of Representatives, leaving only "free exercise of religion" as the closing clause in the measure ultimately passed by Congress and ratified by the states. ${ }^{134}$ Although some scholars have opined that 'the framers viewed 'free exercise of religion' and 'freedom of conscience' as virtually interchangeable concepts,", ${ }^{, 135}$ such assertions are typically aimed at arguing that, at least in the mind of the framers, religion circumscribed conscience, and not, as some modern thinkers might prefer, the other way around. ${ }^{136}$

Leaving aside any debate on the uncertainty at its drafting, the First Amendment's Free Exercise Clause has clearly since been understood as a protector of religious belief, with little room for non-religious conscience. To be sure, there have been cases, mostly during the Vietnam War, where the Supreme Court has "constru[ed] 'religion' broadly to include convictions that are deeply-held, but not 'religious' in any conventional sense of the term."137 Most such cases, though, dealt more with the specifics of the "conscientious objector" provision in the military service statute than any constitutional minimums. ${ }^{138}$ Furthermore, whether in these cases or in those that more directly involve constitutional free exercise,

discussion" on the Senate's deletion of the House version's "rights of conscience" phrase in the final language of the relevant latter phrase of the First Amendment).

132. See Erwin Chemerinsky, Do State Religious Freedom Restoration Acts Violate the Establishment Clause or Separation of Powers?, 32 U.C. DAVIS L. REV. 645, 653 (1999) (noting the "preferred status" of religion in the constitutional context, rather than "all aspects of freedom of conscience").

133. U.S. CONST. amend. I.

134. See McConnell, supra note 100 , at 1488 (discussing deletion of "rights of conscience" in the final draft of the First Amendment).

135. Smith, supra note 120 , at 912 .

136. See id. (asserting that "Congressional discussions [at the First Amendment's drafting] . . . suggest that the framers viewed 'free exercise of religion' and 'freedom of conscience' as virtually interchangeable concepts," with the latter phrase "understood in essentially religious terms" at that time).

137. Id. (citing Welsh v. United States, 398 U.S. 333, 343-44 (1970), United States v. Seeger, 380 U.S. 163, 180-81 (1965), and Torcaso v. Watkins, 367 U.S. 488, 495 n.11 (1961)).

138. See, e.g., Welsh, 398 U.S. at 335 (declining to "pass[] upon the constitutional arguments" given the Court's expansive reading of "religious" in the military exemption statute, which in its present form is found at 50 U.S.C. App. § 456(j) (1990)); Seeger, 380 U.S. at 166 (finding objectors at issue fit the draft exemption for "belief 'in a relation to a Supreme Being,"' thus avoiding any constitutional challenge). 
religion in particular, and not conscience in general, has remained the focal point ${ }^{139}$ - even if some rather obscure or dubiously "religious" beliefs or practices have been found to be within its reach. ${ }^{140}$ In fact, although some might point to cases that have implied protection for atheists or agnostics by the Free Exercise Clause to support a theory of expansion of that provision into a more general conception of conscience, ${ }^{141}$ such instances have invariably framed the issue in terms of defining "religion" for the Clause, and not as a conscience protection effort in the broader, secular sense. $^{142}$

Beyond its restriction to religious conscience, even if broadly construed, the Free Exercise Clause in its application, whether in the governmental workplace (by analogy to the context at hand) or otherwise, is also rather limited by the Supreme Court's holding in Employment Division v. Smith. ${ }^{143}$ There, the Court refused to provide a constitutionallybased exception to Oregon's refusal to pay unemployment benefits to a claimant who was fired for his otherwise illegal, but in his case religious, use of the hallucinogen peyote. ${ }^{144}$ In so ruling, the Court, in an opinion written by Justice Scalia, observed that "the right of free exercise does not relieve an individual of the obligation to comply with a 'valid and neutral

139. See, e.g., Welsh, 398 U.S. at 346 (noting the "broad scope of the word 'religious"" in finding for an exemption under the military service statute); Sherbert v. Verner, 374 U.S. 398, 406 (1963) (coupling the disqualification of conscience objection to working on the Sabbath with religious discrimination).

140. See, e.g., Gonzales v. O Centro Espirita Beneficente Uniao Do Vegetal, $126 \mathrm{~S}$. Ct. 1211, 1216 (2006) (upholding under the Religious Freedom Restoration Act of 1993, 42 U.S.C. $\S 2000 \mathrm{bb}(2000)$, the possible freedom to drink a hallucinogenic tea as a "sincere exercise of religion" despite an otherwise applicable criminal law); Employment Div. v. Smith, 494 U.S. 872 (1990) (considering the ingestion of peyote as a bona fide religious practice under the First Amendment, though rejecting its protection in that case on other grounds); Seeger, 380 U.S. at 166 (approving as "religious" one's "belief in and devotion to goodness and virtue for their own sakes, and a religious faith in a purely ethical creed") (internal citation omitted).

141. See, e.g., Wallace v. Jaffree, 472 U.S. 38, 52-54 (1985) (framing "religion" under the First Amendment in terms of "freedom of conscience," and including within its ambit "the disbeliever and the uncertain").

142. See Thomas C. Berg, Minority Religions and the Religion Clauses, 82 WASH. U. L.Q. 919, 976 (2004) (observing that any free exercise protection for atheists or agnostics that otherwise exists must be justified in religious terms-i.e., "the religious claimant [of relevant rights] - and therefore the atheist or agnostic claimant-still needs to articulate some connection, even if indirect, between the principle of conscience and the belief on a religious matter"). See also Kaufman v. McCaughtry, 419 F.3d 678, 681 (7th Cir. 2005) ("The Supreme Court has said that a religion, for purposes of the First Amendment, is distinct from a 'way of life,' even if that way of life is inspired by philosophical beliefs or other secular concerns.").

143. Smith, 494 U.S. at 872. Congress' subsequent, though not entirely successful, rejection of the Court's decision is discussed infra notes $189-93$ and accompanying text.

144. See id. at 890 ("Oregon may ... deny respondents unemployment compensation when their dismissal results from the use of [peyote]."). 
law of general applicability on the ground that the law proscribes (or prescribes) conduct that his religion prescribes (or proscribes)." "145 Consequently, "[t]he Smith majority opinion rejected free exercise protection [in this context] on the ground that it would produce anarchy with each believer 'a law unto himself."'146 Thus, even religious conscience that is otherwise covered by the First Amendment is limited, at least in its practice if not belief, when it conflicts with a "neutral law of general applicability." 147

Turning to other provisions of the First Amendment, one similarly finds limits for conscience protection, particularly that of a secular variety - a fact that not only has direct implications for public workers, but also should be understood indirectly for those in the private sector in light of the influence constitutional judgments can often have on private relations. ${ }^{148}$ For example, in Lee v. Weisman, ${ }^{149}$ the Supreme Court held that the arrangement by a public school for a rabbi to deliver graduation prayers violated the Establishment Clause. ${ }^{150}$ In so doing, the Court emphasized the need to protect "conscience and belief" from a statesponsored "coercive pressure." 151 Consequently, the "conscience" protected in Lee could be read to include a non-religious, or at least dissenting, version. ${ }^{152}$ And yet again, there are limits, particularly when drawing lessons for the private sector. First, the Court expressly limited its holding to children, stating: "[w]e do not address whether th[e] choice [to participate] is acceptable if the affected citizens are mature adults." 153 In addition, and as others have noted, the Lee holding, by virtue of its constitutional ("state actor") focus, is necessarily limited to public rather than private or "cultural" coercion. ${ }^{154}$ Thus, as with free exercise, "it would

145. Id. at 879 (internal citation omitted).

146. Berg, supra note 142, at 983 (quoting Smith, 494 U.S. at 885).

147. Smith, 494 U.S. at 879 . See also Smith, supra note 120, at 913 ("Under current [free exercise] doctrine, so long as such laws are viewed by the courts as being 'generally applicable' and religiously 'neutral,' no accommodation of religious exercise-and hence of conscience-is required.").

148. See GLENDON, supra note 46, at 3-7 (discussing the influence of modern constitutional law on the rise of "rights" discourse in the culture generally). See also Robert H. Bork, The Judge's Role in Law and Culture, 1 Ave MARIA L. REV. 19, 20 (2003) ("When the Supreme Court, rightly or wrongly, enunciates a principle as constitutional law, people assume that the principle is ... basic to our freedoms.").

149. Lee v. Weisman, 505 U.S. 577 (1992).

150. See id. at 586-92 (giving reasons as to why prayers at issue were not permissible in public school ceremony).

151. Id. at 592.

152. See Smith, supra note 114 , at $930-35$ (on the nature of "conscience" protection in Lee v. Weisman).

153. Lee, 505 U.S. at 593.

154. See Smith, supra note 114, at 932 (proposing the "distinction between government action and private cultural coercion" as a limiting implication of Lee v. Weisman). 
be inaccurate to say that the Court has recognized a right of conscience in any significant sense"155 - whether on the job or anywhere else.

The public-private distinction just noted for establishment is all the more relevant when considering free speech. As such, there is no question that when it applies, the Free Speech Clause (i.e., "Congress shall make no law ... abridging the freedom of speech") $)^{156}$ is powerful. The Supreme Court has described it as "the right of freedom of thought,"157 and has held that the right includes "the right to speak freely and the right to refrain from speaking at all." 158 Yet again, such a right only applies against the state. ${ }^{159}$ Moreover, it is restricted even further in the relevant arena of employment, where the Court has held that although public workers have speech rights, they are largely limited to speaking on "matters of public concern" in ways that do not unduly impair the relevant public employer's functions. ${ }^{160}$ As a result, any conscience-based conflict concerning the actual performance of one's duties would naturally be outside of the protective realm. As the Court stated just last term (2005-06) in Garcetti v. Ceballos, "[g]overnment employers, like private employers, need a significant degree of control over their employees' words and actions; without it, there would be little chance for the efficient provision of public services." $" 161$

The final, albeit controversial, source of arguable "constitutional" protection of conscience that should be explored is "substantive due process." As alluded to in the last section by the quote from Casey, the Supreme Court has used the notion of conscience (or at least "choice") to support an expansive reading of the "due process" clauses of the Fifth and Fourteenth Amendments ${ }^{162}$ for decades. ${ }^{163}$ Yet, at least up to this point, the "liberty" interest supported by such a reading has been limited to state

155. Id. at 940 .

156. U.S. CONST. amend. I.

157. Wooley v. Maynard, 430 U.S. 705, 714 (1977). In Wooley, the Court found that the required carrying of New Hampshire's state motto "Live Free or Die" on a license place notwithstanding a driver's opposition on "moral, religious, and political grounds" conflicted with a First Amendment freedom not to speak. Id. at 713-17.

158. Id. at 714 .

159. See Ashcroft v. Free Speech Coal., 535 U.S. 234, 245 (2002) (observing that the constitutional free speech right generally "bars the government from dictating what we see or read or speak or hear").

160. Garcetti v. Ceballos, 126 S. Ct. 1951, 1957 (2006).

161. Id. at 1958. In support of public employer deference in speech cases, the Court also noted that "the government as employer indeed has far broader powers than does the government as sovereign." Id. (quoting Waters v. Churchill, 511 U.S. 611,671 (1994)).

162. See U.S. CoNST. amend. V ("[n]o person ... shall be deprived of life, liberty, or property, without due process of law"); see also U.S. CoNST. amend. XIV § 1 ("nor shall any State deprive any person of life, liberty, or property, without due process of law").

163. See Planned Parenthood of Se. Pa. v. Casey, 505 U.S. 833, 848-51 (1992) (tracing the development of a "substantive sphere of liberty" under the constitutional "due process" clauses as part of an assessment of statutory limits on abortion). 
action, like all other constitutional provisions save the Thirteenth Amendment. ${ }^{164}$ Furthermore, it has also been largely limited to "personal decisions relating to marriage, procreation, family relationships, child rearing, and education," ${ }^{, 65}$ and not to conscience generally, or most relevant to our present purpose and by analogy, the area of public employment. ${ }^{166}$

In short, the constitutional protection of conscience is limited. First, any coverage that exists is by its nature limited to state action, or, for our purposes, public employment. Second, even in this area, such protection is restricted largely to conscience of a religious sort. Finally, although the meaning of religion, like conscience, has admittedly expanded since the time of the framers, the impact of Smith, together with the relative weakness of free speech and even substantive due process, in the employment arena only further limit conscience rights-even if put in religious terms. Some might applaud; others lament, but the above constitutional review points to significant deference to employers-in this case, governmental ones. ${ }^{167}$ Whether such deference is provided when these very same governments set the rules for private employers, however, is another matter. In fact, as shown by the conscience clause trend explored below, private rights in this context can increasingly be seen as outpacing public ones-a very curious phenomenon indeed.

\section{The New Frontier: Conscience and the Private Realm}

For private employers and employees, of course, it is not constitutional law, but statutory and common law that are the chief regulators (if any) of their bond. Indeed, as described in Part II above, both the at-will presumption and its exceptions are ultimately creatures of judicial or legislative deference or oversight, respectively. It is no different in the conscience arena. In this regard, both federal and state laws have something to say, although the states have truly been the trendsetters for the recent expansion of conscience protection. Pertinent federal law consists largely of religion protection, although it also includes discrete rules on military service and federal contracts. Given these parameters, therefore,

164. The ban on slavery is the only constitutional obligation for private actors. See U.S. CONST. amend. XIII $\S 1$ ("Neither slavery nor involuntary servitude . . . shall exist in the United States.").

165. Lawrence v. Texas, 539 U.S. 558, 574 (2003).

166. See Erwin Chemerinsky, Qualified Immunity: $\$ 1983$ Litigation in the Public Employment Context, 21 TouRo L. REv. 551, 566-68 (2005) (observing, "[s]ince 1937, the Supreme Court and lower courts have been completely unwilling to protect economic rights under substantive due process," and including public employment in the discussion of such rights).

167. See, e.g., Garcetti v. Ceballos, 126 S.Ct. .1951, 1958 (2006) (discussing the necessity of giving latitude to state employers in restricting certain employee freedoms). 
such federal law has been, at least to this point, limited in a manner consistent with the constitutional context noted above. State law, however, has become much more extensive, and although it too has historically focused on religion in a manner similar to most federal law and the traditional cultural understanding, it has increasingly adopted a more general, subjective concept of conscience. In the end, then, it is this state law, more than any federal statute or constitutional rule, that offers the bulk of conscience protection in the workplace. Moreover, in so doing, it is this state law that not only expands worker rights in a way not similarly recognized in the cultural or constitutional realms, but also challenges the at-will rule in a manner heretofore unrecognized in employment law.

\section{Federal Statutory Law}

The primary federal law that arguably concerns conscience, albeit of the religious variety, is Title VII. ${ }^{168}$ As described in Part II above, Title VII covers most private and public employers with fifteen or more employees, ${ }^{169}$ and, along with a host of other bases (e.g., race, gender), prohibits employment discrimination "because of . . religion."170 Like its other protected bases, Title VII covers the mere fact of religious status, yet unlike the others, also includes actions undertaken in connection with religion-at least to a point. ${ }^{171}$ It does this by defining "religion" to include "all aspects of religious observance and practice, as well as belief, unless an employer demonstrates that he is unable to reasonably accommodate to an employee's or prospective employee's religious observance or practice without undue hardship on the conduct of the employer's business."172 Thus, although Title VII goes beyond status and into behavior, it does so in a curious way that defines "religion" itself as including only beliefs or practices that can be "reasonably accommodate[d] . . . without undue hardship." 173 To be sure, this is not exactly a citadel of protection, and it is something that is weakened even further by the Supreme Court's interpretation of "undue hardship" in the landmark 1977 case Trans World Airlines v. Hardison ${ }^{174}$ as any accommodation that "requir[es] [an

168. 42 U.S.C. $\S 2000 \mathrm{e}(2000)$.

169. See id. $\S \S 2000 \mathrm{e}(\mathrm{a}), 2000 \mathrm{e}(\mathrm{b}), 2000 \mathrm{e}-16$ (covering state and local, private, and federal employers, respectively).

170. Id. $\S 2000 \mathrm{e}-2(\mathrm{a})$.

171. See id. § $2000 \mathrm{e}(\mathrm{j})$ (defining “religion").

172. Id.

173. Id. See also Chalmers v. Tulon Co. of Richmond, 101 F.3d 1012, 1018 (4th Cir. 1996) (observing that, by nature of its statutory definition, religion is "in a special category" under Title VII).

174. Trans World Airlines v. Hardison, 432 U.S. 63 (1977). 
employer] to bear more than a de minimis cost"175 - a hardship which the Court there found at $\$ 150$ in overtime pay for a temporary replacement. ${ }^{176}$ Although bills have been introduced in Congress to increase the "hardship" required, including the adoption of the "significant difficulty or expense" test of the Americans with Disabilities Act, ${ }^{177}$ no such legislation has yet passed. ${ }^{178}$

In what could be seen as a counter to the Court's limiting of accommodation by the "de minimis" test, ${ }^{179}$ the Equal Employment Opportunity Commission (EEOC), Title VII's chief enforcement agency, drawing from interpretations of some of the military provisions noted above, declared that it "will define religious practices to include moral or ethical beliefs as to what is right and wrong which are sincerely held with the strength of traditional religious views." 180 Although these merely provide "guidance," and do "not carry the force of regulation," "t81 "the courts have mostly followed the EEOC's lead." 182 Thus, it is more likely that many "beliefs," including even acts of secular conscience, that might not otherwise pass a theologian's test for religion could still fall within the ambit of Title VII accommodation. ${ }^{183}$ And yet, even given the breadth of the EEOC definition, such accommodation is still not terribly difficult given the "de minimis" standard. ${ }^{184}$

175. Id. at 84 .

176. See id. (viewing the option of paying for overtime to a replacement worker on Hardison's Sabbath as an "undue burden"). See also id. at 92 n.6 (Marshall, J., dissenting) (describing the cost for the replacement as " $\$ 150$ for three months, at which time [Hardison] would have been eligible to transfer" out of the conflict).

177. See James A. Sonne, The Perils of Universal Accommodation: The Workplace Religious Freedom Act of 2003 and the Affirmative Action of 147,096,000 Souls, 79 NOTRE DAME L. REV. 1023, 1024-25 (2004) (discussing the 2003 Senate proposal to adopt for religious accommodation under Title VII the "significant difficulty or expense" hardship standard of the Americans with Disabilities Act of 1990, 42 U.S.C. $\$ 12101$ (2000)).

178. See Judy Greenwald, Greater Accommodation Proposed: A Federal Bill Would Set a Higher Standard for Employer Tolerance, Bus. INS., Aug. 15, 2005, at 33 (discussing religious accommodation trends).

179. Cf. 29 C.F.R. $\S \S 1605.2,1605.3$ app. A (2006) (indicating, among other things, that the Equal Employment Opportunity Commission expressly revised these guidelines to "clarify the obligation imposed [under Title VII] to accommodate the religious practices of employees and prospective employees" in light of "concerns raised by Hardison").

180. Id. $\S 1605.1$.

181. Michael Wolf et al., Religion In the WorkPlace: A Comprehensive Guide to LEGAL RIGHTS AND RESPONSIBILITIES 3 (1998).

182. Id. at 28 .

183. See Nottelson v. Smith Steel Workers D.A.L.U. 19806, 643 F.2d 445, 454 (7th Cir. 1981) (observing the broad reach of the EEOC's definition of "religion" for purposes of accommodation under Title VII).

184. See David L. Gregory, Religious Harassment in the Workplace: An Analysis of the EEOC's Proposed Guidelines, 56 MONT. L. REV. 119, 127 (1995) (arguing that the "de minimis" standard articulated by the Supreme Court in Hardison has rendered Title VII 
Aside from Title VII, which again applies to most employers of any decent size, the remaining federal statutory provisions, like the constitutional ones, largely apply only to public - in this case, federalemployees. One exception is the "Church Amendment," which protects both public and private workers, although its protection requires a federal contract. $^{185}$ In any event, the other federal provisions that arguably implicate conscience in employment are the Religious Freedom Restoration Act of 1993 (RFRA) (and related federal personnel laws), ${ }^{186}$ the military service exception noted above, ${ }^{187}$ and the Church Amendment. Of these, the Church Amendment is the most analogous to the state law provisions that, again, are the biggest conscience challenge to at-will employment. ${ }^{188}$

RFRA, which became law in 1993, was passed in direct response to the Supreme Court's decision in Employment Division v. Smith. ${ }^{189}$ As noted earlier in the description of Smith, the Court in that case held that the Free Exercise Clause did not require the government to make exceptions to "neutral law[s] of general applicability" for the benefit of religious practices that might otherwise be affected thereby. ${ }^{190}$ Perceived by many as a slight to religious practice, Congress responded to Smith with RFRA, which requires the federal government ${ }^{191}$ to show a "compelling interest"

"largely meaningless as a source of protection for the religiously observant employee of the secular employer"). See also Wardle, supra note 6, at 218-19 ("[I]t is clear that Title VII provides inadequate protection for the rights of conscience of health care workers.").

185. 42 U.S.C. $\S 300 \mathrm{a}-7$ (2000) (protecting workers who refuse to participate in sterilizations or abortions).

186. See WOLF ET AL., supra note 181, at 7-8 (listing the following as federal protectors of religious practices (in addition to Title VII and the Constitution): 1) federal personnel laws, particularly the religious observance leave provisions (5 U.S.C. $\S 5550 \mathrm{a}(2000)$ ), 2) the Religious Freedom Restoration Act of 1993 (42 U.S.C. $\S 2000 \mathrm{bb}(\mathrm{b})(2000)$ ), and 3) White House Guidelines on Religious Expression in the Federal Workplace). Mr. Wolf and his co-authors also make reference to provisions in President Johnson's 1965 Executive Order No. 11246 for federal contractors and the National Labor Relations Act (29 U.S.C. § 169 (2000)), although, for the most part, the former law simply echoes the requirements of Title VII (see WOLF ET AL., supra note 181, at 4) while the latter, at least to this point, only concerns religious-based objections to dues if one's union membership violates "established and traditional tenets or teaching" of a religion (not conscience in any larger sense) (see id. at 5-6).

187. See 50 U.S.C. app. $\S 456(j)$ (1990) (setting forth the relevant military exemption). See also 32 C.F.R. $\S 75$ (2005) (describing the related conscientious objector regulations).

188. See Cristina Arana Lumpkin, Comment, Does a Pharmacist Have the Right to Refuse to Fill a Prescription for Birth Control, 60 U. MIAMI L. REv. 105, 112 (2005) (commenting on the Church Amendment).

189. See 42 U.S.C. $\S 2000 \mathrm{bb}(\mathrm{b})(1)$ (2000) (providing RFRA's statutory findings, which expressly reject the holding in Employment Div. v. Smith, 494 U.S. 872 (1990)). See also Gonzales v. O Centro Espirita Beneficente Uniao Do Vegetal, 126 S. Ct. 1211, 1216 (2006) (describing RFRA as a "respon[se]" to Smith).

190. Smith, 494 U.S. at 879 (quoting United States v. Lee, 455 U.S. 252, 263 n.3 (1982) (Stevens, J., dissenting)).

191. Although on its face RFRA applies to both federal and state law, the Supreme Court 
for the imposition of a "substantial burden" to "religious exercise" (arguably, a pre-Smith constitutional test). ${ }^{192}$ To be sure, RFRA provides expanded coverage, although again, at least for our purposes, it is limited both to conscience of a religious nature and to federal workers, not to workers generally.

Perhaps the most well-known of all conscience protections arises in the military. Rooted in a long history based not only on the "moral and social value" of conscience, ${ }^{193}$ but also the likely futility of doing otherwise, ${ }^{194}$ Congress has exempted "conscientious objectors" from forced service from the "earliest period of American history."195 The current incarnation of this exemption (which applies, at least at present, in the nondraft setting to those already serving who now seek discharge) covers those "who, by reason of religious training and belief, [are] conscientiously opposed to participating in war in any form, [but expressly refuses to include objections of an] essentially political, sociological, or philosophical view[], or a merely personal moral code."196 The clarifying regulations, which reflect some of the interpretive case law over the years, further define "religious training and belief" as:

Belief in an external power or being or deeply held moral or ethical belief, to which all else is subordinate ... and which has the power or force to affect moral well-being. The external power or being need not be of an orthodox deity, but may be a sincere and meaningful belief which occupies in the life of its possessor a place parallel to that filled by the God of another, or, in the case of ... moral or ethical beliefs, a belief held with the strength and devotion of traditional religious conviction. The term ... does not include a belief which rests solely upon considerations of policy, pragmatism, expediency, or political views. ${ }^{197}$

in City of Boerne v. Flores, 521 U.S. 507 (1998), found its application to state law to be an unconstitutional use of authority under the Fourteenth Amendment.

192. 42 U.S.C. $\$ 2000 \mathrm{bb}(\mathrm{a})(2000)$. The "compelling interest" test of RFRA was drawn from the tests used in Sherbert v. Verner, 374 U.S. 398 (1963), and Wisconsin v. Yoder, 406 U.S. 205 (1972), both of which the Court in Smith refused to apply as a general matter (see Smith, 494 U.S. at 883-85). See also 42 U.S.C. $\S 2000 \mathrm{bb}(\mathrm{b})(1)$ (referring to Sherbert and Yoder among its statutory findings).

193. United States v. Seeger, 380 U.S. 163, 170 (1965) (quoting Harlan Fiske Stone, The Conscientious Objector, 21 Col. UNIV. Q. 253, 269 (1919)).

194. See Colleen M. Garrity, Note, The Religious Freedom Peace Tax Fund Act: Becoming Conscious of the Need to Accommodate Conscience, 64 Онго ST. L.J. 1229, 1234 (2003) (discussing the historical argument of the conscientious objector exemption that "people who are morally opposed to fighting $\mathrm{d}[\mathrm{o}]$ not make good soldiers").

195. Gillette v. United States, 401 U.S. 437, 443 n.8 (1971).

196. 50 U.S.C. app. $\S 456(j)(1990)$.

197. 32 C.F.R. \& 75.3(b) (2005). See also Welsh v. United States, 398 U.S. 333, 341-44 
The accommodations granted to those who qualify for conscientious objector status vary, although they include noncombatant service, alternative civilian work, and even relief from duty. ${ }^{198}$ On the whole then, the military offers a fairly high level of accommodation based on a rather flexible definition of its conscience category of "religious training and belief." 199 The statute restricts itself to "religious training and belief" and it is clear that "some separate conception of religion" short of secular conscience is required. ${ }^{200}$ And yet, the regulations, with their inclusion of "moral or ethical beliefs," 201 stretch almost as far as possible in that direction. ${ }^{202}$ Moreover, although its accommodations mandate an opposition to all wars, and not just particular ones, ${ }^{203}$ its options, including release from duty altogether, reflect a "deep concern for the situation of conscientious objectors. ${ }^{204}$

Finally, the Church Amendment. Like the state laws referenced in Part I above, this statute was passed in 1973 in partial response to Roe $v$. Wade ${ }^{205}$ the Supreme Court's decision of that same year favoring protection of very broad abortion rights. The Church Amendment is

(1970) (including within the term "religious" for purposes of the exemption certain moral or ethical beliefs that would otherwise qualify even where the person does not characterize them as religious); Seeger, 380 U.S. at 176 (1965) (including in the exemption "sincere and meaningful belief which occupies in the life of its possessor a place parallel to that filled by the God of those admittedly qualifying for the exemption").

198. See 50 U.S.C. app. $\$ 456(j)$ (1990) (describing relevant accommodations); see also 32 C.F.R. $\S 75.5$ (2005) (regarding the same).

199. See Thomas C. Berg, The Permissible Scope of Legal Limitations on the Freedom of Religion or Belief in the United States, 19 EMORY INT'L L. REV. 1277, 1291 (2005) (observing the "very broad interpretation" given to religion in the military service context, while noting that the Supreme Court has "never extended the draft-exemption definition to the [Free Exercise Clause] more broadly").

200. Steven D. Jamar, Accommodating Religion at Work: A Principled Approach to Title VII and Religious Freedom, 40 N.Y.L. SCH. L. REV. 719, 751 (1996).

201. 32 C.F.R. $\S 75.3(b)$ (2005).

202. See Jamar, supra note 200 , at 751 (implying that the definition of religion in the military conscientious objector context falls just short of conscience generally, and includes a "broad range of beliefs").

203. See Gillette v. United States, 401 U.S. 437, 443 (1971) (discussing the rule that one must be opposed to "any war and all war" to meet the military conscientious objector exemption).

204. Id. at 445 .

205. 410 U.S. 113 (1973). See also Melissa Seifer Briggs, Comment, Exempt or Not Exempt: Mandated Prescription Contraception Coverage and the Religious Employer, 84 OR. L. REV. 1227, 1232 (2005) (arguing that the Church Amendment was "enacted in response to Roe v. Wade"). It should be noted that, in addition to limiting the implications of Roe generally, the Church Amendment was also designed to protect against claims that any health care provider who received federal funds became a state actor and, therefore, was required to "fulfill the promise" of Roe by performing abortions. See Taylor v. St. Vincent's Hosp., 369 F. Supp. 948, 950 (D. Mont. 1973) (describing Amendment's specific targeting of state action findings). 
considered by many, albeit primarily in the abortion context, to be " $t]$ he first conscience clause." 206 Its original text provides, in pertinent part, that institutions participating in relevant federal health care grant, loan, or contract programs may not:

discriminate in the employment ... of any physician or other health care personnel . . . because he performed or assisted in ... a lawful sterilization procedure or abortion, because he refused to perform or assist in ... such a [sterilization] procedure or abortion on the grounds [of] ... his religious beliefs or moral convictions, or because of his religious beliefs or moral convictions respecting sterilization procedures or abortions. ${ }^{207}$

By way of further changes, the Amendment was extended in 1974 to provide that:

[n]o individual shall be required to perform or assist in the performance of any part of a health service program or research activity funded in whole or in part under a program administered by the Secretary of Health and Human Services if his performance or assistance in the performance of such part of such program or activity would be contrary to his religious beliefs or moral convictions. ${ }^{208}$

Although elements of the Church Amendment have also been expanded in the institutional sector, particularly in the case of hospitals or medical schools that refuse to perform abortions, ${ }^{209}$ the basic employment principle outlined above has remained: in exchange for federal funds, workers (or applicants) in the relevant health care field may not be discriminated against in employment because of their "religious beliefs or moral convictions," whether on sterilization, abortion, or otherwise. ${ }^{210}$ In

206. Briggs, supra note 205, at 1231.

207. 42 U.S.C. $\& 300 \mathrm{a}-7$ (c)(1) (2000).

208. Id. $\S 300 \mathrm{a}-7(\mathrm{~d})$. Although the statutory language appears broad, the legislative history and later court interpretations suggest that the 1974 amendment was not intended to cover all institutions receiving federal funds, but rather only those participating in research and related "programs" that are directly administered by the Department of Health and Human Services. See H.R. REP. No. 93-1148 (1974) (Conf. Rep.), reprinted in 1974 U.S.C.C.A.N. 3634, 3689 (reporting adoption of a limit to the amendment's scope to "entities that receive grants or contracts for biomedical or behavioral research"); Gray by Gray v. Romeo, 697 F. Supp. 580, 590 n.6 (D. R.I. 1988) (refusing to include routine medical treatment in "health service program" coverage).

209. See Leonard J. Nelson, III, God and Woman in the Catholic Hospital, 31 J. LeGis. $69,77-78$ (2004) (discussing the expanded protection for residency programs and hospitals under Medicaid programs).

210. 42 U.S.C. $\& 300 \mathrm{a}-7(\mathrm{c})(1)(2000)$. It should also be noted that a non-discrimination rule for "religious beliefs or moral convictions" on contraception relating to participation in federal health benefits programs is provided under current law. See Transportation, Treasury, Housing and Urban Development, The Judiciary, The District of Columbia, and 
its facial reference to both "religious beliefs" and "moral convictions," the law goes well beyond the federal provisions already described, constitutional or statutory. ${ }^{211}$ Further, in its use of federal funds rather than public employment as the lynchpin, it reaches into the private sector in ways not accomplished by the other federal means. ${ }^{212}$ In fact, even though the law itself is limited to fund recipients under a specific set of federal programs-i.e., programs provided pursuant to the Public Health Service Act, Community Mental Health Centers Act, or the Developmental Disabilities Services and Facilities Construction Act, ${ }^{213}$ or offered under the Secretary of Health and Human Services ${ }^{214}$ - the number of institutions and individuals covered thereby is not insignificant. ${ }^{215}$ Moreover, though its dependence on public funds makes the law an indirect regulation by Congress under the Constitution's "spending clause" rather than a direct mandate, ${ }^{216}$ its preferential option for conscience is clear-particularly in light of its passage immediately following Roe. ${ }^{217}$

Independent Agencies Appropriations Act, 2006, Pub. L. No. 109-115, § 833, 119 Stat. 2396 (2005). See also Nelson, supra note 9, at 148 (discussing both the Church Amendment and an earlier version of the contraception term in the federal benefits program).

211. Compare 42 U.S.C. $\S 300 a-7(c)(1)$ (2000) (offering protection under Church Amendment based on "religious beliefs or moral convictions"), with 50 U.S.C. App. $\S$ 456(j) (1990) (restricting recognition of objections to military service to those based on "religious training and belief," and not "a merely personal moral code").

212. See Davis, supra note 8, at 860 ('[T]he 'Church Amendment,' provides sweeping protection to institutions and individuals with conscientious objections to abortion and sterilization procedures.").

213. See 42 U.S.C. $\S 300 \mathrm{a}-7$ (c)(1) (2000) (conditioning Church Amendment's discrimination protections on receipt of funds under the Public Health Service Act (42 U.S.C. § 201) Community Mental Health Centers Act (42 U.S.C. § 2689), or Developmental Disabilities Services and Facilities Construction Act (42 U.S.C. $\S 6000)$ ).

214. See 42 U.S.C. $\S 300 \mathrm{a}-7$ (d) (2000) (providing protection by way of the Secretary of Health and Human Services).

215. For 2003, federal funds accounted for $21 \%$ of the nation's $\$ 1.6$ trillion health care spending. See Cathy A. Cowan \& Micah B. Hartman, Financing Health Care: Businesses, Households, and Governments, 1987-2003, Health CARE FinanCING ReVIEw (July 2005), tbl.1, available at $\mathrm{http}: / / \mathrm{www} . \mathrm{cms}$.hhs.gov/apps/review/web_exclusives/cowan.pdf. Of this, forty-seven percent was for Medicaid, twenty-seven percent for Medicare, nineteen percent for "other programs," and seven percent as an employer. Id. at tbl.7. Moreover, as Medicare is administered by the Secretary of Health and Human Services and most of the "other programs" just noted are supported by the Public Health Service Act, it could be said that about ten percent (i.e., forty-six percent (Medicare + "other programs") of the twentyone percent overall funding percentage) of the nation's annual health spending is arguably implicated by the Church Amendment. But see supra note 208 (arguing that only certain federal institutions are covered under the Amendment).

216. Cf. South Dakota v. Dole, 483 U.S. 203, 210 (1987) (describing Congress' indirect power under the Spending Clause of Article I of the United States Constitution as exceeding its direct regulatory authority).

217. See Davis, supra note 8, at 859-60 (noting that, "spurred by the Supreme Court's pronouncement in Roe v. Wade," the Church Amendment "provides sweeping protection" 


\section{State Law}

As noted above, the states have been the chief trailblazers when it comes to conscience protection in the workplace. In general, this trend has been marked by four distinct approaches. First, like Title VII, most states offer protection for religion, and, thus, for beliefs and actions arising from religious-based conscience. ${ }^{218}$ Second, similar to the Church Amendment, yet typically lacking any public funds-based limitation, many states also provide procedure-specific protection in the areas of abortion, sterilization, and to a lesser (yet growing) extent, artificial contraception and the execution of a living will or similar acts. ${ }^{219}$ Third, and most significant in relation to an otherwise applicable at-will rule, some states have expanded into a general conscience protection, albeit still primarily limited to health care, without any procedural restrictions at all ${ }^{220}$ - and, as noted in this article's introduction, the trend is going in this direction. ${ }^{221}$ Fourth and finally, through catch-all "public policy" protections (which can also include "whistleblower" and anti-retaliation rules), still other states provide coverage for certain conscience-driven beliefs or actions, although typically in an indirect manner that emphasizes the relevant external policy (e.g., the crime being reported for which an employee seeks "whistleblower" protection) rather than any value of conscience per se. ${ }^{22}$

With regard to religious conscience, most states follow the Title VII model described above. At present, forty-six states and the District of Columbia prohibit discrimination on the basis of religion in private employment. $^{223}$ The typical language for such provisions is similar to that

for conscientious objection to abortion).

218. See BUCKLEY \& GREEN, supra note 87, at tbl.3-1, pt. A (providing a list of relevant state provisions on religious discrimination in employment).

219. See Nelson, supra note 9, at 149 (observing that, as of 2005, all the states, with the lone exception of Vermont, "provide[d] at least some kind of protection for rights of conscience for at least some health care professionals under at least some circumstances").

220. See id. at 149-50 (observing that Illinois, Mississippi, and Washington all have "comprehensive conscience protection" for individual health care providers).

221. See, e.g., NCSL REPORT, supra note 37 (indicating that broad health care conscience bills (i.e., those without procedure limits) have been recently introduced in Alabama, Arkansas, Michigan, Missouri, Rhode Island, South Dakota, Texas, and Vermont). Others also include New Jersey (see A.B. 2016, 212th Leg., Reg. Sess. (N.J. 2006)) and West Virginia (see S.B. 41, 77th Leg., Reg. Sess. (W. Va. 2006)).

222. See, e.g., Frank J. Cavico \& Nancy M. Cavico, Employment-At-Will, Public Policy, and the Nursing Profession, 8 QuINNIPIAC HEALTH L.J. 161, 164-74 (2005) (discussing the "public policy" exception to the at-will rule in the nursing objection context).

223. See BUCKLEY \& GREEN, supra note 87 , at tbl.3-1, pt. A (listing religion discrimination laws in forty-six states and the District of Columbia; noting that related statutes in Georgia, Mississippi, and North Carolina only apply to "public employment" and Alabama's only applies to legislative workers). See also JAMES O. CASTAGNERA ET AL., TERMINATION OF EMPLOYMENT $\S 2.1$ (2002) (providing a chart indicating that every state has 
of Title VII (i.e., an employer may not "discriminate against any individual with respect to his compensation, terms, conditions, or privileges of employment, because of such individual's . . religion"). ${ }^{224}$ Thus, in addition, and not surprisingly, "state courts presented with discrimination claims that arise under state law [also] often look to the federal case law interpreting Title VII for guidance.,225 Yet, with regard to workplace accommodation-here, the accommodation of acts driven by conscience of a religious nature - the states are a somewhat mixed bag. ${ }^{226}$ Most follow the "de minimis" standard articulated for Title VII by the Supreme Court in Hardison $; 227$ others offer a more stringent (or at least different and,

some form of protection from religious discrimination, whether in public or private employment).

224. 42 U.S.C. $\S 2000 \mathrm{e}-2$ (a) (2000). See also LARSON, supra note 77 , at $\S \S 114.02$ 114.02[2] (noting that state discrimination laws largely "mirror Title VII and other major federal statutes," though generally require fewer than the fifteen workers for coverage); Eyana J. Smith, Comment, Employment Discrimination in the Firm: Does the Legal System Provide Remedies for Women and Minority Members of the Bar?, 6 U. PA. J. LAB. \& EMP. L. 789,795 (2004) ("Many of the state discrimination laws closely mirror Title VII.").

225. Joanne C. Brant, "Our Shield Belongs to the Lord": Religious Employers and a Constitutional Right to Discriminate, 21 HAST. CONST. L.Q. 275, 283 (1994).

226. For a state survey of accommodation covering many of the laws in the notes that follow, see Peter M. Panken et al., Religious Discrimination: Multi-State Survey, VPB1116 ALI-ABA 1 (2000).

227. The jurisdictions following the "de minimis" (explicitly or implicitly) test include: Alaska (Wondzell v. Alaska Wood Products, Inc., 583 P.2d 860, 864 (Alaska 1978)); California (Soldinger v. Northwest Airlines, Inc., 51 Cal.App.4th 345, 370 n.11 (1996)); District of Columbia (D.C. CoDE. § 2-1402.11(c)(1) (West 2001)); Florida (Greenfield v. City of Miami Beach, 844 F. Supp. 1519, 1524 n.1 (S.D. Fla. 1992)); Idaho (Bowles v. Keating, 606 P.2d 458, 462 (Idaho 1979)); Illinois (Olin Corp. v. Fair Employment Practices Comm'n, 367 N.E.2d 1267, 1272 (Ill. 1977)); Iowa (King v. Iowa Civil Rights Comm'n, 334 N.W.2d 598, 602 (lowa 1983)); Kentucky (Ky. Comm'n on Human Rights v. Commonwealth, 564 S.W.2d 38, 40 (Ky Ct. App. 1978)); Maine (Me. Human Rights Comm'n v. Local 1361, United Paperworkers Int'l, 383 A.2d 369, 381 (Me. 1978)); Missouri (Sedalia No. 200 School Dist. v. Mo. Comm'n on Civil Rights, 843 S.W.2d 928 , 930 (Mo. App. 1992)); Montana (see Panken, supra note 226, at 93 (discussing the Montana Human Rights Commission)); New Jersey (see id. at 103 (discussing the "useful[ness]" of Title VII in interpreting New Jersey law)); Ohio (Franks v. Nat'l Lime \& Stone Co., 740 N.E.2d 694, 697-700 (Ohio Ct. App. 2000)); Oklahoma (see Panken, supra note 226, at 128 (discussing Oklahoma Human Rights Commission)); Oregon (Heller v. Ebb Auto Co., 8 F.3d 1433, 1440 (9th Cir. 1993)); Pennsylvania (Pa. State Univ. v. Commonwealth, 505 A.2d 1053, 1056 (Pa. Commw. Ct. 1986)); Tennessee (DePriest v. Puett, 669 S.W.2d 669, 675 (Tenn. Ct. App. 1984)); Texas (Grant v. Joe Myers Toyota, Inc., 11 S.W.3d 419, 422-23 (Tex. App. 2000)); Vermont (Gallip v. City of Rutland, 656 A.2d 635, 640 (Vt. 1994)); Virginia (VA. CODE ANN. § 2.2-3901 (2005)); West Virginia (see Panken, supra note 226, at 167 (discussing West Virginia Human Rights Commission)). Although there is little case law or other guidance, the statutes for Arkansas (ARK. CODE ANN. § 16-123-103 (2006)), South Carolina (S.C. CODE ANN. § 1-13-30(k) (2005)), and South Dakota (S.D. ADMIN. R. 20:03:10:01 (1986)) contain sufficiently similar language to Title VII to suggest they also follow its "de minimis" test. 
therefore, necessarily more substantial than "de minimis") test, ${ }^{228}$ while still others offer no accommodation at all. ${ }^{229}$ On the whole, whether out of express adoption or silence, most offer up to the "de minimis" level of Hardison (roughly twenty-three states and the District of Columbia) ${ }^{230}$ or nothing at all (roughly nineteen states). ${ }^{231}$ In short, similar to Title VII, such state religious discrimination laws are not exactly a haven for conscientious objectors at work. ${ }^{232}$

As noted above, many states followed the lead of the federal Church Amendment in the early 1970 s by protecting conscience in the discrete arena of abortion and related reproductive matters. ${ }^{233}$ As of this writing, forty-seven states have "conscience clauses" on the refusal to perform abortions and, of these, forty offer direct protection from related employment discrimination and/or recrimination. ${ }^{234}$ The most common

228. The jurisdictions that require, explicitly or implicitly, something other than a "de minimis" hardship include: Arizona (ARIz. REV. STAT. ANN. § 41-1461 (2004)); Colorado (see Panken, supra note 226, at 22 (discussing Colorado Civil Rights Commission)); Kansas (KAN. AdMIN. Regs. 21-33-1(b) (1975)); Maryland (MD. ANN. CodE art. 49B, § 15(f) (2003)); Massachusetts (MASs. GEN. LAwS ANN. ch. $151 \mathrm{~B} \&$ 4(1A) (West 2004)); New Hampshire (N.H. CodE AdMIN. R. ANN. HuM. § 404.02(a) (1998)); New York (NY EXEC. LAW $\S 296(1)(d)(1)(M c K i n n e y ~ 2005)$ ); North Dakota (N.D. CENT. CoDE 14-02.4-02(17) (2004)).

229. The jurisdictions that give no accommodation for religious practices (or are silent on the matter) include: Connecticut (Corey v. Avco-Lycoming Div., 307 A.2d 155, 162 (Conn. 1972)); Delaware (see Panken, supra note 226, at 28 (addressing Delaware law)); Hawaii (see CASTAGNERA, supra note 223, at $\S 14.3$ (discussing HAW. REV. STAT. ANN. $\S$ 378-2 (2004)); Indiana (see Panken, supra note 226, at 49 (addressing Indiana law)); Louisiana (LA. REV. STAT. ANN. § 23:332 (2003)); Michigan (Wessling v. Kroger Co., 554 F. Supp. 548, 552 (E.D. Mich. 1982)); Minnesota (MINN. STAT. ANN. $\$ 363$ A.08 (West 2004)); Nebraska (see Panken, supra note 226, at 95 (citing NEB. REV. STAT. ANN. $\S 48-$ 1004 (LexisNexis 2002)); Nevada (see CASTAGNERA, supra note 223, at $\$ 31.3$ (citing NEV. Rev. Stat. AnN. §613.330 (LexisNexis 2006)); New Mexico (N.M. STat. AnN. § 28-1-7 (LexisNexis Supp. 2005)); Rhode Island (see CASTAGNERA, supra note 223, at $\$ 43.3$ (citing R.I. GEN. LAWS $\S 28-5-7$ (2003)); Utah (see id. at $\S 48.3$ (citing UTAH CODE ANN. $\S 34 A-5-$ 106(1)(a) (2005)); Washington (see id. at $\$ 51.3$ (citing WASH. REV. CODE ANN. $\$ 49.60 .180$ (West 2002)); Wisconsin (Am. Motors Corp. v. Dep't of Indus., Labor and Human Relations, 305 N.W.2d 62, 77 (Wis. 1981)); Wyoming (see Panken, supra note 226, at 174 (discussing WYO. STAT. ANN. § 27-9-105 (2005))). As discussed above, there are also four states (Alabama, Georgia, Mississippi, North Carolina) that do not bar discrimination in private work at all (including non-accommodation). See BUCKLEY \& GREEN, supra note 87, at tbl.3-1, pt. A (listing states).

230. See supra notes 227-28.

231. See supra note 229.

232. See Wardle, supra note 6, at 217-19 (describing weakness of "de minimis" test in conscience context).

233. See Davis, supra note 8 , at 862 (summarizing the series of procedure-specific state "conscience clause" laws that were passed along with the federal Church Amendment in the wake of Roe)

234. The relevant state "abortion" statutes with direct employment discrimination protection are: ARK. CODE ANN. § 20-16-601(b) (2005); CAL. HEALTH \& SAFETY CODE $\S$ 
phrasing for such provisions is exemplified by the law in Florida, which provides:

Nothing in this section [on state abortion law] shall require any hospital or any person to participate in the termination of a pregnancy, nor shall any hospital or any person be liable for such refusal. No person who is a member of, or associated with, the staff of a hospital, nor any employee of a hospital or physician in which or by whom the termination of a pregnancy has been authorized or performed, who shall state an objection to such procedure on moral or religious grounds shall be required to participate in the procedure which will result in the termination of pregnancy. The refusal of any such person or employee to participate shall not form the basis for any disciplinary or other recriminatory action against such person. ${ }^{235}$

Like the foregoing Florida provision, "[m]ost conscience clauses contain no exceptions to the prohibitions and protection provided." ${ }^{236}$ Moreover,

123420(a) (West 2006); Colo. Rev. Stat. ANN. $§ 18-6-104$ (West 2004); Del. Code ANN. tit. 24, § 1791 (2005); Fla. STAT. ANN. § 390.0111(8) (West 2002); Ga. CODE ANN. § 1612-142 (2003); IDAHO CODE ANN. § 18-612 (2004); 745 ILl. CoMP. STAT. ANN. 30/1 (West 2002); IND. CODE ANN. § 16-34-1-6 (West 1997); IOWA CODE ANN. \& 146.1 (West 2005); Kan. Stat. ANN. § 65-443 (2002); Ky. ReV. Stat. ANN. § 311.800(5)(b) (LexisNexis 2001); LA. Rev. Stat. ANN. § 40:1299.31(a) (2001); ME. ReV. STAT. ANN. tit. 22, § 1592 (2004); Md. Code ANN., Health-Gen. $\$ 20-214$ (a)(2)(ii) (LexisNexis 2005); Mass. GeN. Laws ANN. ch. 112, § 12I (West 2003); MICH. CoMP. LAWS ANN. $§ 333.20182$ (West 2001); MINN. STAT. ANN. $§ 145.414$ (a) (West 2005); MISS. CodE ANN. § 41-107-5(3) (West 2005); Mo. ANN. STAT. $\S 197.032(2)$ (West 2004); MONT. CODE ANN. $\S 50-20-111(2)$ (2005); NeB. REV. STAT. § 28-338 (LexisNexis 2003); NEV. Rev. STAT. ANN. $§ 632.475(2)$ (LexisNexis 2004); N.J. STAT. ANN. § 2A:65A-3 (West 2000); N.M. STAT. ANN. § 30-5-2 (Lexis 2004); N.Y. CIV. RIGHTS LAW § 79-i (McKinney 1992); N.C. GEN. STAT. § 14-45.1(e) (2005); N.D. CENT. CODE § 23-16-14 (2002); OHIO Rev. CODE ANN. § 4731.91(C) (West 2004); OKLA. STAt. ANN. tit. 63, § 1-741(B) (West 2004); 18 PA. Cons. Stat. ANN. $\S 3213$ (d) (West 2000); R.I. GEN. LAWS § 23-17-11 (2001); S.C. CODE ANN. § 44-41-50(c) (2002); S.D. CODIFIED LAws $\S 34-23 A-13$ (2004); TeX. OCC. CODE ANN. $\S 103.002$ (Vernon 2004); UTAH CODE ANN. § 76-7-306(1) (2003); VA. CODE ANN. § 18.2-75 (2004); WASH. REV. CODE ANN. $\S 70.47 .160$ (2)(a) (West 2002); WIS. STAT. ANN. § 253.09(3) (West 2004); WYo. STAT. ANN. $\S 35-6-106$ (2005). The state laws on more general rights of refusal (typically phrased in terms of immunity from civil or criminal liability) are: ALASKA STAT. $\S$ 18.16.010(b) (2004); ARIZ. Rev. STAT. ANN. § 36-2151 (2003); ConN. AGENCIES REgS. $\S$ 19-13-D54 (2005); Haw. Rev. STAT. ANN. \$ 453-16(d) (LexisNexis 2005); Or. Rev. STAT. $\S 435.485$ (2003); TENN. CODE ANN. § 39-15-204 (2003); W. VA. CODE ANN. § 16-2F-7 (LexisNexis 2001). At present, Alabama, New Hampshire, and Vermont have no such abortion-related conscience law.

235. FLA. STAT. ANN. $§ 390.0111(8)$ (West 2002). As its language indicates, this Florida law addresses both employment discrimination and potential civil or criminal liability.

236. Wardle, supra note 6, at 194 . Indeed, of the state abortion-based laws cited above (see supra note 234), the only restrictions are that thirteen states require objections in writing (i.e., Arizona, California, Colorado, Georgia, Kentucky, Massachusetts, Montana, Nevada, New York, Rhode Island, South Carolina, Virginia, Wisconsin), while two states (California, Pennsylvania) exempt abortion-specific practitioners. 
although the Florida law refers to "moral or religious grounds," well "[m]ore than one-third of the jurisdictions that have conscience clauses do not specify the grounds for conscientious objection.",237 In short, state law conscience provisions on abortion are remarkable both in their range of persons covered and in their refusal to limit themselves to religious-only objections.

Other procedures targeted by states for rights of refusal and the number of such targeting states include: sterilization (eighteen), ${ }^{238}$ artificial contraception (for pharmacists or prescribing physicians) (fourteen), ${ }^{239}$ and the withdrawal or imposition of relevant life-sustaining treatment

237. Wardle, supra note 6, at 196. Of the state abortion-based laws cited above (see supra note 234), the states that do not specify particular grounds for objection are: Alaska, Arkansas, Delaware, Hawaii, Illinois, Kansas, Louisiana, Maine, Maryland, Minnesota, Nebraska, New Jersey, North Dakota, Ohio, Oklahoma, Oregon, South Carolina, South Dakota, Tennessee, Texas, West Virginia, and Wyoming.

238. The conscience-based state laws relating to sterilization are: ARK. CODE ANN. $\S 20-$ 16-304(4)-(5) (2005); Colo. Rev. STAT. ANN. § 25-6-102(9) (West 2005); Fla. STAT. ANN. $\S 381.0051(6)$ (West 2002); Ga. CODE ANN. $\$$ 49-7-6 (2002); 745 ILl. CoMP. STAT. ANN. 70/5 (West 2002); Kan. STAT. ANN. § 65-446 (2002); ME. Rev. Stat. AnN. tit. 22, § 1903(4) (2004); MD. CODE ANN., Health-GeN. § 20-214(a)(2)(ii) (LexisNexis 2005); MASS. GEN. LAWS ANN. ch. 112, §121 (West 2003); MISS. CODE ANN. \$ 41-107-5(3) (West 2005); N.J. Stat. ANN. § 2A:65A-3 (West 2000); OR. REV. STAT. $\$ 435.225$ (2003); R.I. GeN. LAWS § 23-17-11 (2001); TENN. CODE ANN. § 68-34-104(5) (2001); Wash. Rev. CODE ANN. $\S 70.47 .160(2)$ (a) (West 2002); W. VA. CODE ANN. § 16-2B-4 (LexisNexis 2001); WIS. STAT. ANN. § 253.09(3) (West 2004); WYo. STAT. ANN. § 42-5-101 (2005). Of these jurisdictions, nine (Arkansas, Colorado, Florida, Georgia, Maine, Oregon, Tennessee, West Virginia, Wyoming) implicitly address sterilization through "family planning" or "contraceptive procedures" language, while three (Illinois, Mississippi, Washington) address it with a more generic "health care" clause. In addition, four of these states (Georgia, Oregon, West Virginia, Wyoming) largely limit their coverage to the public provision of such services.

239. The conscience-based state laws relating to artificial contraception, whether by pharmacist or physician, are: ARK. CODE ANN. § 20-16-304(4)-(5) (2005); CAL. BUS. \& Prof. Code § 733(b)(3) (West Supp. 2006)); Colo. Rev. STAT. ANN. § 25-6-102(9) (West 2005); Fla. Stat. AnN. \& 381.0051(6) (West 2002); Ga. CoMp. R. \& RegS 480-5-.03 (West 2005); 745 Ill. Comp. Stat. ANN. 70/5 (West 2002); ME. REV. STAT. ANN. tit. 22, § 1903(4) (2002); Miss. CODE ANN. § 41-107-5(3) (West 2005); OR. REV. STAT. § 435.225 (2003); 18 Pa. Cons. STAT. ANN. $\S 3213$ (d) (West 2000); S.D. COD. LaWs $\S 36-11-70$ (2004); TENN. CODE ANN. § 68-34-104(5) (2001); WASH. REV. CODE ANN. § 70.47.160(2)(a) (West 2002); W. VA. CodE ANN. § 16-2B-4 (LexisNexis 2001); Wyo. STAT. ANN. § 42-5-101 (2005). Of these states, five (California, Georgia, Illinois, Mississippi, Washington) address contraception by broader pharmaceutical or "health care" clauses, while three others (Oregon, West Virginia, and, it appears, Wyoming) largely limit coverage to the public provision of such services. Finally, although the Pennsylvania and South Dakota laws seem limited to abortion, some have argued that they cover certain "contraceptives" as well. See, e.g., Karissa Eide, Comment, Can a Pharmacist Refuse to Fill Birth Control Prescriptions on Moral or Religious Grounds?, 42 CAL. W. L. REV. 121, 134-35 (2005) (discussing the South Dakota law). 
(twelve). ${ }^{240}$ Although sterilization provisions typically "piggy-back" on language from corresponding abortion or contraception statutes, ${ }^{241}$ most contraception and end-of-life provisions stand alone in their particular coverage of conscientious objection. ${ }^{242}$ The most typical form of contraception-specific statute can be seen in the relevant Colorado statute, which provides:

No private institution or physician, nor any agent or employee of such institution or physician, shall be prohibited from refusing to provide contraceptive procedures, supplies, and information when such refusal is based upon religious or conscientious objection, and no such institution, employee, agent, or physician shall be held liable for such refusal. ${ }^{243}$

Likewise, the most typical language that is used to target specifically endof-life care can be seen in the relevant Iowa statute, which provides:

Notwithstanding a contrary health decision of the attorney in fact, the health care provider is not subject to criminal prosecution, civil liability, or professional disciplinary action for failing to withhold or withdraw health care necessary to keep the principal alive. However, the attorney in fact may make provisions to transfer the responsibility for the care of the principal to another health care provider. ${ }^{244}$

240. The conscience-based state laws relating to care at the end of life are: 745 ILL. Comp. Stat. AnN. 70/5 (West 2002); Iowa Code ANN. § 144B.9(2) (West 2005); MinN. STAT. ANN. § 145C.11(c) (West 2005); Miss. CODE ANN. § 41-107-5(3) (West 2005); N.H. Rev. Stat. AnN. § 137-H:6 (LexisNexis 2006); N.D. Cent. Code $\S 23-06.5-12(3)$ (LexisNexis Supp. 2005); OKLA. STAT. ANN. tit. 63, $\$ 3101.9$ (West 2004); Or. REv. STAT. $\S$ 127.885 (4) (2003); 20 PA. CONS. STAT. ANN. $\$ 5409$ (b) (West 2003); S.D. CoD. LAWS $\S 36-$ 11-70(3) (2006); WASH. REV. CODE ANN. $\$ 70.47 .160(2)$ (a) (West 2002); WYo. STAT. ANN. $\S 35-22-410(a)(v)(2005)$. Of these states, three (Illinois, Mississippi, Washington) address such issues through a broader "health care" clause, while two others (New Hampshire, Wyoming) address it through "living will" legislation.

241. Of the sterilization laws listed above (see supra note 238), nine states (Arkansas, Colorado, Florida, Georgia, Maine, Oregon, Tennessee, West Virginia, Wyoming) include sterilization with contraception, five states (Maryland, Massachusetts, New Jersey, Rhode Island, Wisconsin) couple it with abortion, and three states (Illinois, Mississippi, Washington) address it with a generic "health care" clause. Only one state (Kansas) has a separate provision dealing with sterilization.

242. See supra notes $239-40$ (listing directly targeted laws on contraception, with the exception of broader clauses in California, Illinois, Mississippi, and Washington, and on end-of-life care, with the exception of broader clauses in Illinois, Mississippi, and Washington, and, arguably, New Hampshire and Wyoming).

243. COLO. REv. StAT. ANN. $§ 25-6-102(9)$ (West 2005). This Colorado law is virtually identical to statutes in Arkansas and Tennessee, and is quite similar to those in Florida, Maine, and Wyoming. ARK. CODE ANN. § 20-16-304(5) (2005); TENN. CODE ANN. § 68-34104(5) (2001); Fla. Stat. ANN. $§ 381.0051(6)$ (West 2002); ME. Rev. Stat. ANN. tit. 22, § 1903(4) (2002); WYO. STAT. ANN. § 42-5-101 (2005).

244. IOWA CODE ANN. $\S 144 \mathrm{~B} .9(2)$ (West 2005). This lowa law is quite similar to 
In a manner similar to their abortion counterparts, most state conscience laws concerning sterilization, contraception, or end-of-life care decisions do not include "undue hardship" or other accommodation limits, ${ }^{245}$ nor do they restrict their recognized objection grounds to religion. ${ }^{246}$

Turning to the more general "health care" conscience clauses, which, as noted at the start of both this article and this section, are growing in popularity and naturally pose a greater challenge to at-will authority than the procedure-specific rules just addressed, three states stand out from the others-Illinois, Mississippi, and Washington. ${ }^{247}$ In the employment context, these laws (which, at least in Illinois and Mississippi, are referred to as "Health Care Rights of Conscience Acts") provide, in pertinent part, as follows:

\section{Illinois}

It shall be unlawful for any person, public or private institution, or public official to discriminate against any person in any manner, including but not limited to, licensing, hiring, promotion, transfer, staff appointment, hospital, managed care entity, or any other privileges, because of such person's conscientious refusal to receive, obtain, accept, perform, assist, counsel, suggest, recommend, refer or participate in any way in any particular form of health care services contrary to his or her conscience. ${ }^{248}$

\section{Mississippi}

It shall be unlawful for any person, health care provider, health care institution, public or private institution, [or] public official . . . to discriminate against any health care provider in any manner based on his or her declining to participate in a health care service that violates his or her conscience. For purposes of this chapter, discrimination includes, but is not limited to:

statutes in Minnesota, North Dakota, Pennsylvania, and Wyoming. See MinN. STAT. AnN. $\S$ 145C.11(c) (West 2005); N.D. CENT. CODE $§ 23-06.5-12(3)$ (2002); 20 PA. CONS. STAT. ANN. § 5409(b) (West 2000); WYO. STAT. ANN. § 35-22-410(a)(v) (2005).

245. Of the sterilization, contraception, and end-of-life laws cited above, the only limits on the relevant rights of refusal are: 1) written objections to sterilization must be filed in four states (Massachusetts, Oregon, Rhode Island, Wisconsin), to contraception in two states (California, Oregon), and to end-of-life care in one state (Pennsylvania), 2) there is an "hardship" limit for contraception in California and a limit for abortion providers in Pennsylvania for arguably contraceptive "abortifacients," and 3) there are duties to transfer to ensure care for contraceptives in one state (Georgia) and end-of-life care in eight states (Iowa, Minnesota, New Hampshire, North Dakota, Oklahoma, Oregon, Pennsylvania, Washington). See supra notes $238-40$ (citing the relevant statutes).

246. Of the sterilization and contraception laws cited above, only Florida, Georgia, and West Virginia restrict their protections to religious conscience. See supra notes 238-39. Of the end-of-life laws, none are limited to religious objections. See supra note 240.

247. See Nelson, supra note 9, at 149-50 ("The other states' right-of-conscience laws are not as comprehensive as those of Illinois, Mississippi, and Washington.").

248. 745 Ill. Comp. Stat. ANN. 70/5 (West 2002). 
termination, transfer, refusal of staff privileges . . . adverse administrative action, demotion, loss of career specialty, reassignment to a different shift, reduction of wages or benefits, refusal to award any grant, contract, or other program, refusal to provide residency training opportunities, or any other penalty, disciplinary or retaliatory action. ${ }^{249}$

\section{Washington}

No individual health care provider, religiously sponsored health carrier, or health care facility may be required by law or contract in any circumstances to participate in the provision of or payment for a specific service if they object to so doing for reason of conscience or religion. No person may be discriminated against in employment or professional privileges because of such objection. $^{250}$

In covering all health care services, the statutes in Illinois, Mississippi, and Washington go well beyond the procedure-specific laws of the other states. $^{251}$ Moreover, in refusing to include an "undue hardship" or other accommodation limit of any significance, ${ }^{252}$ they go further than their

249. MISS. CODE ANN. $\S 41-107-5(3)$ (West 2005).

250. WASH. REV. CODE ANN. $\S 70.47 .160(2)$ (a) (West 2002).

251. As alluded to in note 239 above, Georgia and California have broad conscience language that is fairly similar to Illinois, Mississippi, and Washington, yet such provisions are largely limited to pharmaceuticals. See supra note 239 (citing, in pertinent part, CAL. Bus. \& PROF. CODE § 733(b)(3) (West Supp. 2006), and GA. COMP. R. \& REGS. § 480-5.03 (n) (West 2005)). It should also be noted that broad protection similar to that provided in Illinois, Mississippi, and Washington may also arguably exist in many states through what one might call "individual health order" laws. These laws, which exist in about seventeen states and are virtually uniform in their language, typically provide that, "[a] health care provider may decline to comply with an individual health care instruction or health care decision for reasons of conscience." CAL. Prob: CODE $\S 4734$ (a) (West 2006). See also ARIZ. REV. STAT. ANN. § 36-3205(C)(1) (2003); AlaSKa Stat. $§ 13.52 .060(e)$ (2004); Del. Code ANN. tit. 16, § 2508(e) (2003); Ga. CODE ANN. § 31-36-8(2) (2001); HaW. ReV. STAT. ANN. § 327E-7(e) (LexisNexis 2004); IDAHO CODE § 39-4508 (2002); IND. CODE § 30-5-910(2) (West 1994); ME. Rev. Stat. ANN. tit. 18-A, § 5-807(e) (1998); MD. Code ANN., HEALTH-GEN. § 5-613 (LexisNexis 2005); Mass. Gen. Laws ANN. ch. 201D, $§ 14$ (1981); Mo. ANN. STaT. $\S 404.830(1)$ (West 2001); N.H. REv. STAT. ANN. § 137-H:6 (LexisNexis 2006); N.M. STAT. ANN. § 24-7A-7(E) (2000); 20 PA. Cons. STAT. ANN. $\S 5409$ (a) (West 2003); VT. STAT. ANN. tit. 18, § 9713 (2005); Wyo. STAT. ANN. § 35-22-410(a)(v) (2005). However, although not always restricted by direct language, these laws are invariably written in the context of adherence to "living wills" or the direction of a health care proxy, and, thus, are likely inapplicable to health care decisions generally. $C f$. Matthew S. Ferguson, Note, Ethical Postures of Futility and California's Uniform Health Care Decisions Act, 75 S. CAL. L. REV. 1217, 1218 (2002) (describing the relevant California law as a "comprehensive codification of end-of-life decisions").

252. The only boundaries on the rights of refusal in Illinois, Mississippi, and Washington are the Illinois rule that one cannot breach a procedure-specific contract or publicly funding arrangement and the requirement of written notice of such refusals to enrollees in Washington's public health program by participating providers. See 745 IlL. COMP. STAT. 
counterparts in Title VII or analogous state provisions on religious practice accommodation. ${ }^{253}$ Finally, although it is arguable that "conscience" has a more limited meaning than "choice" in the context of these statutes, Illinois simply defines it as a "sincerely held set of moral convictions,",254 Mississippi includes "religious, moral or ethical principles,"2ss and Washington offers no definition at all. ${ }^{256}$ Obviously, these three statutes are limited to the health care arena, yet there is no question that their expansion in the future, both within that arena for other states and in the larger workplace as a whole, would not be too surprising. ${ }^{257}$ In fact, since the passage of the Mississippi law in 2004, there have been at least ten other states considering broad conscience protection, ${ }^{258}$ and at least five other

AnN. 70/13 (West 2002); Miss. Code. ANN. § 41-107-3 (West 2005); WaSh. Rev. Code ANN. $\S 70.47 .160$ (2)(b) (West 2002).

253. Compare 42 U.S.C. $\S 2000 \mathrm{e}(2000)$ (Title VII) (outlining federal accommodation provisions) with statutes cited supra note 229 (showing differences in state religious accommodation laws).

254. 745 Ill. COMP. STAT. ANN. 70/3(e) (West 2002).

255. Miss. CODE ANN. § 41-107-3(h) (West 2005).

256. See generally WASH. REV. CODE ANN. $§ 70.47 .020$ (West 2002) (providing definitions for terms used elsewhere in the statute).

257. See Stein, supra note 12, at A1 (discussing the conscience "trend" in the pharmacy arena, and quoting conscience advocate Steven $\mathrm{H}$. Aden as stating: "[m]ore and more pharmacists are becoming aware of their right to conscientiously refuse .... We are on the very front edge of a wave that's going to break.").

258. See The Guttmacher Monthly State Update: Major Developments in 2006 [hereinafter, 2006 Guttmacher Report], available at http://www.guttmacher.org/statecenter/updates/index.html (noting that, as of August 1, 2006, bills had been introduced in nine states that year "establishing the right to refuse to provide medical care in general"). For example, a bill in Michigan provides, "[a] health care provider may object as a matter of conscience to providing or participating in a health care service on ethical, moral, or religious grounds." H.B. 4741, 93rd Leg., lst Reg. Sess. (Mich. 2005). A Missouri bill states, "[n]o person, health care provider, health care institution, public or private institution, [or] public official ... may discriminate against any health care provider in any manner based on the provider's declining to participate in a health care service that violates the provider's conscience." H.B. 1539, 93rd Gen. Assemb., 2d Reg. Sess. (Mo. 2006). See also H.B. 609, 2006 Reg. Sess. (Ala. 2006); A.B. 2016, 212th Leg., Reg. Sess. (N.J. 2006); H.B. 6793, 2006-06 Reg. Sess. (R.I. 2006); H.B. 1184, 81 st Leg., Reg. Sess. (S.D. 2006); S.B. 41, 77th Leg., 2nd Sess. (W. Va. 2006). Bills with similar text were also introduced in 2005 . See S.B. 1141, 85th Gen. Assemb., Reg. Sess. (Ark. 2005); S.B. 1016, 79th Leg., Reg. Sess. (Tex. 2005); H.B. 183, 68th Biennial Sess. (Vt. 2005). See also Tresa Baldas, Fighting Refusal to Treat: Conscience Clauses Hit the Courts, NAT'L. L.J., Feb. 7, 2005, at 1 (discussing 2004 bills). It should be noted that there are also a few states with bills pending that, seemingly contrary to conscience, would mandate the provision of health care, usually in the area of contraceptives. See Stein, supra note 12 , at $\mathrm{Al}$ (describing pending legislation in four states). Although such bills are not necessarily mutually exclusive with conscience, as evidence by a similar, recently enacted California law that mandates the filling of prescriptions, yet also includes a conditional ("undue hardship") conscience exemption. CAL. BUS. \& PROF. CODE $\S 733$ (b)(3) (West Supp. 2006). 
states considering similarly broad laws in the pharmacist context. ${ }^{259}$ Most such bills are entitled "Health Care Rights of Conscience Acts"260 (or, perhaps in the pharmaceutical context, "Pharmacist's Freedom of Conscience Acts") ${ }^{261}$ and all offer essentially the same universal protection based on "conscience" (defined most commonly as reflecting "religious, moral, or ethical" principles) ${ }^{262}$ as their counterparts in Illinois, Mississippi, and Washington (i.e., any "health care service") ${ }^{263}$ (or, in the pharmacy area, any "particular type of prescription"). ${ }^{264}$

Among the factors that distinguish the foregoing state laws (and proposed bills), whether specific or general, from their federal counterpart in the Church Amendment is that the state laws are generally not based on a provision of public funds or participation in a public health program. ${ }^{265}$ Instead, most "vindicate a general right to refuse,"266 and, thus, easily surpass any federal conscience law, both in theory and practice. Furthermore, with limited exception, most such laws offer few, if any, limits to the refusal rights they provide. ${ }^{267}$ In the end, therefore, although

259. See 2006 Guttmacher Report, supra note 258 (counting state laws). See also NCSL REPORT, supra note 37 (summarizing pending and recently enacted conscience laws for pharmacists as of July 2006).

260. Of the general conscience bills referenced in note 258 above, those from Alabama, Arkansas, Missouri, Rhode Island, Vermont, and West Virginia are referred to as "health care rights of conscience acts."

261. See, e.g., H.B. 1383, 104th Gen. Assemb., Reg. Sess. (Tenn. 2005).

262. See bills cited supra note 258 (providing the proposed general conscience bills in Alabama, Arkansas, New Jersey, Michigan, Missouri, Rhode Island, South Dakota, Texas, Vermont, and West Virginia, all of which use a variant of the "religious, moral, or ethical" definition of conscience).

263. See id. (providing the proposed conscience bills, all of which cover any "health care service").

264. H.B. 1383, 104th Gen. Assemb., Reg. Sess. (Tenn. 2005). See also H.F. 2597, 84th Leg., Reg. Sess. (Minn. 2006); GA. CoMP. R. \& REGS $\S 480-5-.03$ (West 2005) (noting that they each cover "any prescription").

265. See Nelson, supra note 9, at 150 (observing that the Church Amendment and its progeny "are connected to the receipt of federal funds or to specific federal programs, which makes their scope limited").

266. Wardle, supra note 6, at 191.

267. See id. at 194 ("Most conscience clauses contain no exceptions to the prohibitions and protections provided."). Again, the only limits in Illinois, Mississippi, and Washington are a contract/public program breach in Illinois and notice in Washington. See supra note 252 (discussing the boundaries). Of the pending bills, only Michigan requires notice, and only it and Texas have limits for emergencies or cases when the task is a central job duty. See bills cited supra note 258 . With regard to pharmacists, although California's law provides both "reasonable accommodation" and "undue hardship" limits, the bills in Pennsylvania and Tennessee only require alternatives for customers and that the refusal be put in writing, respectively. CAL. BUS. \& Prof. CODE $\S 733$ (b)(3) (West Supp. 2006); H.B. 2217, Reg. Sess. (Pa. 2005); H.B. 1383, Reg. Sess. (Tenn. 2005)). The law in Georgia and the bill in Minnesota have no limits at all. GA. COMP. R. \& REGS $\S 480-5-.03$ (West 2005); H.F. 2597, 84th Leg., 2005-06 Sess. (Minn. 2006). 
they are admittedly limited to the health care arena at this point, it is these laws that provide the starkest challenge to the at-will rule in the conscience context, and their repercussions will be felt well into the future. Indeed, as one commentator put it recently, "[h]ow we decide this is going to have a long-lasting impact on our society.",268 Perhaps they can be seen as logical responses to the Supreme Court's holdings in Smith (i.e., generally upholding "valid and neutral law[s] of general applicability" against constitutional accommodation challenges) ${ }^{269}$ or Hardison (i.e., only requiring the accommodation of religious practices under Title VII up to a "de minimis" level), ${ }^{270}$ and yet, as written, such laws go well beyond mere nullification of these rulings.

The final source of protection for conscience, although arguable, comes from what could be called "public policy and related matters of concern." Public policy grounds typically protect employees from retaliation for engaging or refusing to engage in certain acts, and, thus, the argument goes, could offer protection for the exercise of conscience. Indeed, "in the 1970s and 1980s the highest courts of many states agreed to recognize a 'public policy exception' to the at will rule, although they differed in the latitude they would allow in identifying the sources of public policy for determining whether a discharge was actionable."271 At present, forty-five states recognize a form of "wrongful discharge based on public policy violations." 272 Generally speaking, however, even in those states that provide liberal "public policy" grounds, the use of such grounds is fairly limited as a conscience guardian. As one scholar has noted in the pharmacy area,

Generally, the public policy exception has been limited to . . . [being] discharged for 'refusing to engage in an illegal activity at the behest of the employer; exercising a public duty; asserting a legal right or privilege; or whistleblowing.' None of these categories protects a pharmacist who refuses to fill a prescription on moral or religious grounds. ${ }^{273}$

It is clear that the "public policy" exception not only requires a

268. Stein, supra note 21, at A6 (quoting Gene Rudd of the Christian Medical \& Dental Associations).

269. Employment Div. v. Smith, 494 U.S. 872, 879 (1990) (quoting United States v. Lee, 455 U.S. 252, 263 n.3 (Stevens, J., concurring)).

270. Trans World Airlines v. Hardison, 432 U.S. 63, 84 (1977).

271. Leonard, supra note 96 , at 635.

272. BUCKLEY \& GREEN, supra note 87 , at tbl.5-4 (indicating some form of a "public policy" cause of action in all states except Alabama, Georgia, Rhode Island, Vermont, and Virginia).

273. Lumpkin, supra note 188 , at 116 (quoting Donald W. Herbe, Note, The Right to Refuse: A Call for Adequate Protection of a Pharmacist's Right to Refuse Facilitation of Abortion and Emergency Contraception, 17 J.L. \& HEALTH 77, 95 (2002-2003)). 
"[c]lear mandate of public policy,"274 it also must involve something beyond a mere personal interest or right. ${ }^{275}$ As such, "[i]n order to be a 'public policy,' the policy plainly must inure to the benefit of the public or be done for the good of the public."276 Perhaps in the limited instance of the "public policy" protections for "political activities" that exist in a few states, ${ }^{277}$ one might infer a level of conscience protection, yet even these rules are typically conceived of as supporting the important, and admittedly extracurricular, "public policy" of voting rather than, as in the case of the typical conscience clause, objections to the actual performance of job tasks. ${ }^{278}$ Thus, in the end, although conscience is undoubtedly an important value in modern society, there is also little doubt that such a deeply personal concern, even if collectivized, does not yield a generally applicable interest sufficient to invoke a "public policy" basis of protection. ${ }^{279}$ In fact, if it did, there would be little need for any affected state to pass conscience legislation in the first place.

\section{WHOSE FREEDOM?: BALANCING EMPLOYER AND EMPLOYEE INTERESTS}

In light of the foregoing exploration of the at-will rule in Part II and conscience in Part III, the dissonance of the modern expansion of conscience in the workplace, at least in the health care arena, is laid bare. Granted, the at-will presumption has been eroded by numerous exceptions in the past few decades, and, therefore, it is surely not the stalwart prerogative of employers that it was in the time of Horace Wood. ${ }^{280}$ However, as noted above, these other exceptions (e.g., union protection, Title VII non-discrimination, state tort/contract rules), unlike the Illinoisstyle conscience laws, primarily serve an "anti-prejudice" function and do

274. See Carlson, supra note 54, at 514 (quoting Geary v. United States Steel Corp., 319 A.2d 174, $180(\mathrm{~Pa}$. 1974), where the Court recognized an at-will exception concerning the reporting of unsafe products).

275. See Cavico \& Cavico, supra note 222, at 168-170 (distinguishing "public policy" from personal interest).

276. Id. at 168-69.

277. See also BUCKLEY \& GREEN, supra note 87, at tbl.3-1, pt. B (listing California, District of Columbia, Louisiana, Nevada, North Carolina, and Oregon as jurisdictions that have protections against "political orientation" discrimination in private employment).

278. For example, the relevant provision of California's "political action" nondiscrimination law, CAL. LAB. CODE $\S 1101$ (West 2003), has been expressly described as supporting a "public policy" of the right to vote together with "any incidents of that right." Lockheed Aircraft Corp. v. Superior Court of Los Angeles County, 171 P.2d 21, 25 (Cal. 1946).

279. See Davis, supra note 8, at 851-59 (commenting on the limits of the "public policy" cause of action for conscience).

280. See Ballam, supra note 6, at 653-65 (discussing evolution of at-will rule exceptions) 
not otherwise exempt relevant employees from fulfilling the requirements of their respective jobs. ${ }^{281}$ Of course, simply because the modern trend of conscience coverage expands beyond its "anti-prejudice" forbearers does not necessarily mean that such an expansion is unwarranted. In the end, however, upon examination of the underlying policies of both the at-will rule and this conscience trend, as well as the implications resulting from their confrontation, such an inconsistency can become quite disconcerting - and, as it presently seems, will only become more so in the future. $^{282}$

\section{A. Back to Basics: An At-Will Rejoinder}

Let us begin with an obvious, admittedly circular, maxim: the primary purpose of business is business. Or, to extend it a bit, "[w]hile businesses may have a social conscience and try to be responsive to their employees, businesses are in business to make money."283 They are not the family, nor are they the state. ${ }^{284}$ Certainly, there are many businesses, such as health care entities, that are also designed for "moral ends ... such as rendering charitable service, relieving suffering, . . . curing the sick, or saving life."285

281. See, e.g., Christine Jolls, Commentary: Antidiscrimination and Accommodation, 115 HARV. L. REV. 642, 643 (2001) (observing that, unlike special accommodation rules, "[t]he canonical idea of 'antidiscrimination' in the United States condemns the differential treatment of otherwise similarly situated individuals on the basis of race, sex, national origin, or other protected characteristics"). Two exceptions to the "prejudice" principal in federal law can be seen in the relevant accommodation provisions for religion in Title VII, 42 U.S.C. $\$ 2000 \mathrm{e}(\mathrm{j})(2000)$, and for a qualified "disability" in the Americans with Disabilities Act of 1990 (ADA), 42 U.S.C. $\S 12101$ (2000). Of course, as noted in Part III, both Title VII and the ADA, and unlike the growing conscience trend, only require "reasonable accommodation" and do not require any "undue burden" of an employer. Compare 42 U.S.C. $\S \S 2000 \mathrm{e}(\mathrm{j})$ (Title VII accommodation rule), and 12112(b)(5)(A) (ADA accommodation rule), with Wardle, supra note 6 , at 191 (observing that most conscience laws "vindicate a general right to refuse"). Furthermore, and as also noted in Part III, regarding the more analogous Title VII provisions for religion accommodation, the "de minimis" test adopted by the Court in Trans World Airlines v. Hardison (432 U.S. 63, 84 (1977)), effectively causes that provision to not significantly alter the non-discrimination principle in any event. See Sonne, supra note 177, at 1062 (arguing that a "de minimis" test "fulfills the 'equal treatment' antiprejudice goal without imposing inordinate costs on the relevant parties").

282. See Vischer, supra note 10 , at 84 (describing conscience in the pharmacy context as part of "a rapidly expanding and intensifying conflict"). See also GLENDON, supra note 46, at 16 (commenting on the modern American tendency to submit that, "if rights are good, more rights must be even better").

283. JoAnn C. Maxey, Am I a Partner Because I'm Good or Because . . ?, ARK. LAW., Autumn 1993, at 41, 45 .

284. See Robert G. Kennedy, Corporations, Common Goods, and Human Persons, 4 AVE MARIA L. REV. 1, 24 (2006) (distinguishing the business corporation, the family, and society as a whole).

285. Wardle, supra note 6 , at 185. 
And yet, even in such cases, the "bottom line" is still a fundamental goal which, if nothing else, is evidenced by the predominance of the "cost" factor in the modern "health care crisis" debate. ${ }^{286}$ This bottom line, of course, is no excuse for failing to honor the human dignity of those in one's employ, ${ }^{287}$ nor should it be interpreted to suggest that businesses should be, or are, only concerned with wealth maximization. ${ }^{288}$ And yet, profit is undoubtedly a factor without which (at least in our current system) there would be no employment in the first place. Furthermore, even to the extent that some, including this author, might argue for an increase in corporate responsiveness to the interests of its affected constituencies, whether internal (e.g., workers, investors) or external (e.g., customers, society at large), does not necessarily mean that such an increase is, or should be, dictated by law. ${ }^{289}$

Given the foregoing commercial purposes of employers (and, frankly, employees as well), the at-will presumption is clearly no accident. Once again, as described in Part II, the traditional supports for the at-will rule are the "internalities" (i.e., factors that arise within the employment relationship) of freedom of contract, free enterprise, and property rights, and the "externalities" (i.e., factors relating more to the market or community) of economic efficiency and judicial economy. ${ }^{290}$ Turning first to the internalities, freedom of contract, which is viewed by its proponents as "tend[ing] both to advance individual autonomy and to promote the efficient operation of labor markets," contemplates that "the parties should be permitted . . . to adopt [any] form of contract if they so desire,",291 and, thus, there should be no default rule for term length. Free enterprise

286. See Ceci Connolly, Higher Costs, Less Care: Data Show Crisis in Health Insurance, WASH. POST, Sept. 28, 2004, at A01 (discussing, among other things, the financial interests of providers as part of the health insurance "crisis" in the United States).

287. See Pope John Paul II, Encyclical Letter on the Hundredth ANNIVERSARy of Rerum Novarum [Centesimus Annus] ๆ 35 (St. Paul ed., 1991) ("Profit is a regulator of the life of a business, but it is not the only one: other human and moral factors must also be considered which, in the long term, are at least equally important for the life of a business.").

288. See Kennedy, supra note 284, at 25-26 (describing the non-economic measures of business "success"). See also Leo L. Clarke et al., The Practical Soul of Business Ethics: The Corporate Manager's Dilemma and the Social Teachings of the Catholic Church, 29 SEATTLE U. L. REV. 139, 150-53 (2005) (describing a range of purposes for a corporation).

289. See, e.g., Clarke et al., supra note 288, at 203-04 (positing that "ethical considerations" are already within a corporation's legal power); CHRISTOPHER D. STONE, Where the Law Ends: The Social Control of Corporate Behavior 93-110 (1975) (commenting on the limits of law in increasing "social responsibilities" of a corporation). See generally Steven R. Hirschtick, Book Review: The Conscience of a Corporation, 9 LOY. L.A. L. REV. 976 (1976) (summarizing Stone's argument).

290. For discussions on these traditional supports for the at-will rule, see Carlson, supra note 54; Massingale, supra note 68; Hylton, supra note 69; Morriss, supra notes 70 \& 71 .

291. Epstein, supra note 4, at 951. 
suggests that the law in this arena exists largely to "serve as the glue ... [of] society where individuals . . control their own destiny and advance through individual effort and discipline," and, thus, although employers and employees are free to contract, they are not required to do so. ${ }^{292}$ And, finally, property rights theory provides that the employer's creation of "a job slot" (or, from the employee's perspective, the filling of that "slot") is "a form of private property," and, thus, is presumed subject only to the limits that are imposed by the parties themselves ${ }^{293}$-limits which, incidentally, can include factors beyond mere profit. ${ }^{294}$

Turning to external considerations, the most commonly cited is that of economic or market efficiency. As Professors Mayer Freed and Daniel Polsby once noted, leaving aside any moral obligations that employers might otherwise have to their employees, the at-will regime "persist[s]" in private employment because it is "generally the 'efficient' solution as between employers and employees." $" 295$ As such, the rule permits the parties to choose for themselves and, in so doing, maximize their respective interests in the larger economy rather than be subjected to an across-theboard "cause" rule that, quite possibly, neither party would select if otherwise given the option. ${ }^{296}$ In a more general sense, the other external support for the at-will presumption arises from the law itself - namely, the matter of judicial economy or, more to the point, the competency of law to intervene at all. In this sense, it is argued that "using the courts" is a

292. Ballam, supra note 6, at 683 .

293. Hylton, supra note 69, at 1752. See generally William B. Gould, IV, The Idea of the Job as Property in Contemporary America: The Legal and Collective Bargaining Framework, 1986 BYU L. REv. 885 (1986) (discussing the impact of "the job as property" rationale in contemporary law).

294. See generally Vischer, supra note 10 (emphasizing the role of an employer as an "intermediate" (i.e., between individual consumers or employers and the state) moral actor in the "conscience clause" debate, and noting the general absence of such emphasis in the scholarly literature).

295. Mayer G. Freed \& Daniel D. Polsby, Just Cause for Termination Rules and Economic Efficiency, 38 EMORY L.J. 1097, 1098 (1989) (responding to "market failure" challenges to at-will power like disparate bargaining and imperfect information by citing, inter alia, the ability of workers to compete and the uncertainty that they, much less their employers, would be better off under a mandatory tenure system that would almost certainly come at a higher (albeit largely regulatory-based) cost).

296. See Morriss, supra note 70, at 1902-03 (discussing the market efficiency of the atwill rule). See also Jesse Rudy, What They Don't Know Won't Hurt Them: Defending Employment-At-Will in Light of Findings that Employees Believe They Possess Just Cause Protection, 23 Berkeley J. EMP. \& LAB. L. 307, 309-12 (2002) (arguing that Professor Verkerke's data suggesting the overwhelming selection by employers and employees of the at-will rule supports the use of the presumption even if employees lack complete information as to their pre-contractual status); J. Houlte Verkerke, An Empirical Perspective on Indefinite Term Employment Contracts: Resolving the Just Cause Debate, 1995 WIs. L. REv. 837, 864-69 (1995) (providing data suggesting that, even when given the choice, most employers and employees choose the at-will rule). 
"costly" choice, both in terms of money and information (and/or expertise), that ultimately does more harm than good. ${ }^{297}$ By shifting relevant problems (to the extent they exist) from the parties to the courts, the law inevitably, and regrettably, acts more as a blunt sword than as an exacting scalpel.

Of course, there may be times when the law should act, such as in cases of racial or gender prejudice, public safety, or, for that matter, the enforcement of actual contracts, where natural justice can be seen to necessarily outweigh market efficiency. ${ }^{298}$ Indeed, there is no question that in such cases, the law typically imposes well-justified erosions to the economic free will of employers in the public interest. And yet, such exceptions must be carefully selected, and, as is argued herein, it is far from clear that a presumptive right of employee conscience is among them - particularly when we are dealing with private actors (i.e., employers and employees) who are otherwise largely presumed to be equal in their ability and right to choose their own paths, whether based in conscience or not.

\section{B. Employee Conscience: A "Yes, But" Proposition}

As discussed in Part III above, there is no question that an individual's conscience is something that is accorded a significant level of respect in culture and law, at least as a general matter. In this regard, "freedom of conscience" has been seen as "an essential element of a democratic society,"299 and certainly in terms of one's relationship with the "democratic" state, such recognition can often be found. Though perhaps a bit broad in light of the Supreme Court's holding in Smith, ${ }^{300}$ the oft-quoted words of the late Chief Justice Charles Evans Hughes summarize the traditional position well: "in the forum of conscience, duty to a moral power higher than the state has always been maintained." ${ }^{301}$ Consequently, " $[\mathrm{g}]$ enerally off the table of twenty-first century public debate is any suggestion that an individual's conscience is the proper object of government regulation., ${ }^{302}$ However, in the relevant context at handnamely, private employment-such respect has been largely left up to the affected parties (at least prior to the recent conscience trend). ${ }^{303}$ And, for

297. Morriss, supra note 70 , at $1934-35$.

298. Even the renowned libertarian, Professor Richard Epstein, acknowledges that there are "infrequent cases in which discharge of the contract at will is inconsistent with the performance of some public duty or with the protection of some public right." Epstein, supra note 4, at 952.

299. Nelson, supra note 9, at 143-44.

300. Employment Div. v. Smith, 494 U.S. 872, 879 (1990) (upholding a "neutral law of general applicability" against challenge under the Free Exercise Clause).

301. United States v. Macintosh, 283 U.S. 605, 633 (1931) (Hughes, C.J., dissenting).

302. Vischer, supra note 10 , at 84.

303. Cf. Wardle, supra note 6 , at 226 (expounding on, in his view, a "profoundly 
the four reasons articulated below, such deference is well-founded.

First, as to the meaning of conscience, employers are at a particular disadvantage. They, unlike the state, do not exist simply for the sake of their constituents-in this case, their workers. To be sure, they must honor the dignity of their employees. And yet, they exist for business, not as chief guardians of rights. Furthermore, even where they have a moral duty, it should be clear, direct, and easy to apply. Conscience accommodation is not necessarily easy, and if the related "evolutionary" trend described in Part III above on the meaning of conscience generally takes hold here, ${ }^{304}$ the process will only become all the more difficult. Consider the following effort by Professors Christopher Eisgruber and Lawrence Sager at defining what conscience means:

An important mark of a well-formed person is an internal gyroscope that pulls her toward doing the right thing and away from doing the wrong thing. As right and wrong are understood here, self-interest-in an immediate, material, short-term senseis only coincidentally congruent with rectitude. The tug of this gyroscope toward the right thing is consciously experienced, but in many forms: as raw impulse, as deep but unlocated conviction, or as fully articulate and located within a scheme of belief. The provenance or bona des of this tug is similarly and associatedly diverse: if it is consciously acknowledged at all, it may range from the command of a deity, to the interpreted understanding of a covenant, to a mystic and intuitively driven sense, to a constructed and coherent, but free-standing system of moral judgment. Under some circumstances-chronic and life-shaping, or acute and focused-this pull toward rectitude becomes a central, dominating feature of a person's motivation and selfidentity. When these circumstances obtain, and a person acts on them, she is performing an act of conscience. ${ }^{305}$

With complete respect to these esteemed professors, the foregoing is not exactly as easy as reciting the Ten Commandments. Granted, the difficulty in summarizing what one means by "conscience" does not necessarily diminish its importance. And yet, should the manager of a local Wal-Mart, or for that matter, the managing partner of a Wall Street firm, be required by law to figure it out? Perhaps they should try, but whether they must is another matter. Moreover, even if they are relieved of the task somewhat by the broad definitions of conscience that increasingly operate in the

inadequate" protection of conscience in law as of 1993).

304. See, e.g., Pell, supra note 104, at 25 (commenting on the shift of "conscience" from a referencing of truth to personal autonomy in modern cultural parlance).

305. Christopher L. Eisgruber \& Lawrence G. Sager, The Vulnerability of Conscience: The Constitutional Basis for Protecting Religious Conduct, 61 U. CHI. L. REV. 1245, 126869 (1994). 
current trend, ${ }^{306}$ the result may be a greater recognition of "conscience," but the absolute manner in which it is imposed largely eviscerates any assertion to its being a balanced public policy. In fact, unlike the conscience trend, even when it comes to religion-which one might argue could extend almost as far in its definition-most relevant law (perhaps even as a nod to this arguable uncertainty) only requires "de minimis" accommodation. ${ }^{307}$

Second, even if one accepted some level of accommodation for conscience in the workplace, the current conscience trend, once again, is absolute- even up to the point of shielding workers from performing the essential functions of their jobs. As described in Part III above, the laws in Illinois, Mississippi, and Washington, as well as the proposed legislation in at least nine other states (Michigan is somewhat of an exception), offer no "reasonable" or "undue hardship" limits in their respective accommodation mandates. ${ }^{308}$ Further, most related pharmacy provisions (either in effect or which have been proposed in at least five states) are similar in the absolute nature of their refusal rights. ${ }^{309}$ This wholesale approach might be more understandable if, in a manner consistent with other anti-discrimination jurisprudence, their targets were prejudicial attitudes on the conscientious beliefs (or status) of employees that would not otherwise affect their job performance. $^{310}$ The provisions at issue here, however, necessarily "involve[] more than mere belief: [they] entail[] acting-living-in accordance with central convictions." 311 As such, an employee's conscience becomes the trump card. Even if used sparingly at present, the

306. As noted in Part III.C.2 above, the relevant conscience laws presently in existence offer extremely open-ended definitions of conscience or no definition at all. See 745 ILL. COMP. StAT. ANN. 70/3(e) (West 2002) (defining "conscience" as "a sincerely held set of moral convictions"); MISS. CODE ANN. § 41-107-3(h) (West 2005) (describing "conscience" as including "religious, moral or ethical principles"); WASH. REV. CODE ANN. $§ 70.47 .020$ (West 2002) (offering no definition of conscience at all).

307. See Trans World Airlines v. Hardison, 432 U.S. 63, 84 (1977) (using the "de minimis" accommodation test for religious practice under Title VII); supra notes 227-29 (discussing the relevant state laws). See also Gregory, supra note 184, at 127 (discussing the relative weakness of the "de minimis" accommodation standard).

308. See generally note 267 (describing the lack of limitations in employer accommodation requirements within various state laws).

309. See id. (describing relevant lack of limitations in the pharmacy context by citing examples of the dearth of limitations in Pennsylvania, Tennessee, Georgia and Minnesota).

310. Indeed, if "prejudice" (which can be defined as "opinion formed . . . without knowledge or examination of the facts" (THE AMERICAN HERITAGe DiCTIONARY 1384 (4th ed. 2000)) is truly the "canonical idea of 'antidiscrimination' in the United States" (Jolls, supra note 281 , at 643), then protection of one's personal opinions, if not acts, could be seen as consistent with such law. But see Eugene Volokh, Deterring Speech: When is it "McCarthyism"? When is it Proper?, 93 CAL. L. REv. 1413, 1440-42 (2005) (positing that viewpoint discrimination by a private employer is not as pernicious as other forms of status discrimination or as dangerous as similar discrimination by a governmental entity acting as such).

311. Smith, supra note 120 , at 923 . 
latent potential of such a rule renders it a "sleeping giant" of rights for whose awakening the consequences would be without precedent. Granted, the breadth of such measures could likely be seen as an inevitable consequence of the increasing complexity of ethical issues brought about by advances in technology, particularly in the health care field. ${ }^{312}$ Yet, even still, as the Supreme Court of New Jersey once observed in the "public policy" setting, "[c]haos would result if a single doctor engaged in research were allowed to determine, according to his or her individual conscience, whether a project should continue." ${ }^{313}$ This, of course, is not meant to suggest that "public policy" limits or non-discrimination do not have a role, but simply that a blanket conscience law goes too far.

Third, the relevant conscience mandates for private firms are largely inconsistent with the rules the government otherwise sets for itself, notwithstanding the possibility that any "disparate power" argument supporting conscience protection in the first place would be even stronger in its case. Indeed, "[p]rivate employer power is substantial, but it isn't as dangerous as coercive government power." ${ }^{\text {"314 }}$ That being said, there is no precedent in the public sector for what these provisions propose for all employers, whether private or public. As the Supreme Court opined in Smith in the religion context,

To make an individual's obligation to obey ... contingent upon the law's coincidence with his religious beliefs, except where the State's interest is "compelling"-permitting him, by virtue of his beliefs, to "become a law unto himself"-contradicts both constitutional tradition and common sense. ${ }^{315}$

Or, again, as this very same court asserted as recently as May 2006 in the speech context, "[g]overnment employers, like private employers, need a significant degree of control over their employees' words and actions; without it, there would be little chance for the efficient provision of public services." ${ }^{316}$ If the foregoing is true for public employment, why should it not be all the more true in the private sector? To be sure, in response to Smith, the federal government and many states have imposed on themselves higher duties of accommodation through measures such as the

312. See Rob Stein, Health Workers' Choice Debated: Proposals Back Right Not to Treat, WASH. POST, Jan. 30, 2006, at A01 (describing the role that technological advances in medical research have played in conscience clause politics).

313. Pierce v. Ortho Pharmaceutical Corp., 417 A.2d 505, 514 (N.J. 1980) (citing Report of the Ad Hoc Committee on the Principles of Medical Ethics, AM. MED. Ass'N 3 (1979)).

314. Volokh, supra note 310 , at 1440.

315. Employment Div. v. Smith, 494 U.S. 872, 885 (1990) (quoting Reynolds v. U.S., 98 U.S. $145,167(1878))$.

316. Garcetti v. Ceballos, 126 S. Ct. 1951, 1958 (2006) (citing Connick v. Myers, 461 U.S. $138(1983))$. 
RFRA. ${ }^{317}$ However, these self-imposed restrictions are limited to religion, not conscience generally. Moreover, the fact remains that, though perhaps powerful, the authority of the private employer cannot reasonably be compared to that of the state under the circumstances in which conscience is typically invoked there-e.g., military conscription, enforcement of criminal laws.

As an aside, the public-private distinction is similarly important when considering the converse trend of state mandates "against" conscience. Indeed, although the topic at hand concerns measures by states to require accommodation, there have also been efforts to inhibit accommodationeven if employers are otherwise disposed. ${ }^{318}$ Such provisions typically concern the provision of contraceptives or other health products or treatment, but they do not necessarily end there. ${ }^{319}$ Although such laws do not forbid employer accommodation per se, they naturally diminish the employer's ability to accommodate all workers or otherwise adopt any general policy on the provision (or non-provision) of the relevant product or procedure. In fact, given Title VII's narrow definition of "religious entities" for purposes of its exemption for "mission-based" hiring (i.e., it only exempts "a religious corporation, association, educational institution, or society," and not businesses that otherwise might want to pursue religious, or conscience-based, goals), ${ }^{320}$ one could even make the argument that the very law chiefly responsible for protecting conscience, at least of a religious variety, ends up infringing on it. ${ }^{321}$ To this point, those engaged in the conscience clause debate have, for the most part, waged a winner-take-all battle, often pitting one side's conscience claims against the other's. ${ }^{322}$ In light of the public-private distinction, however, perhaps no legal mandates, period, would be a fair compromise.

317. Religious Freedom Restoration Act, 42 U.S.C. $\$ 2000 \mathrm{bb}-2000 \mathrm{bb}-4$ (2000). See also Eugene Volokh, Freedom of Expressive Association and Government Subsidies, 58 STAN. L. REV. 1919, 1949-51 (2006) (discussing state schemes that provide for a right to religious accommodation).

318. See Stabile, supra note 18, at 741-746 (discussing the current fight of the Catholic Church to decline coverage under related health care plans for contraceptives on the grounds of conscience despite mandatory contraceptive coverage laws).

319. See Davey \& Belluck, supra note 13, at Al (discussing state laws that would require pharmacists to fill any legal prescription including the "morning after" pill).

320. 42 U.S.C. $\$ 2000 \mathrm{e}-1$ (a) (2000).

321. See, e.g., Jamar, supra note 200 , at 727 (distinguishing religion discrimination from race or gender in so far as " $[t]$ he religious freedom interests of the employer and the employee are both of the first magnitude"). See also Catholic Charities of Sacramento, Inc. v. California, 85 P.3d 67, 98-102 (Cal. 2004) (Brown, J., dissenting) (discussing the impact of narrow definitions of "religious employer" in contraceptive law exemptions).

322. See Stein, supra note 12, at A01 (discussing the "pitched" nature of the debate). See also Vischer, supra note 10, at 116 ("In much of our heated public discourse, the mere invocation of individual conscience does not bring clarity, much less the clarity presupposed by the zero-sum terms in which resolutions are framed."). 
Fourth, and perhaps most importantly, the uncompromising mandates presently in vogue unduly burden the relationship between employers and employees by converting what should only be a moral problem into a legal one. As Professor Mary Ann Glendon has pointed out, the conversion of moral duties into legal "rights" often comes at a cost:

The strident rights rhetoric that currently dominates American political discourse poorly serves [our] strong tradition of protection for individual freedom .... [This] stark, simple rights dialect puts a damper on the processes of public justification, communication, and deliberation upon which the continuing vitality of a democratic regime depends. It contributes to the erosion of the habits, practices, and attitudes of respect for others that are the ultimate and surest guarantors of human rights. ${ }^{323}$

Leaving things in the hands of the parties does risk conflict. ${ }^{324}$ Yet it does not necessarily spell doom for the interests that otherwise give rise to the "rights" at issue. Indeed, one need only look to the heart of much of the current controversy-the pharmacy counter-to see examples of the parties "working it out." In this regard, "pharmacy chains, including Walgreens, Wal-Mart and CVS, have instituted ... policies ... to balance pharmacists' and customers' rights." ${ }^{325}$ As one spokeswoman for Walgreens recently put it,

We obviously do have pharmacists with individual moral and ethical beliefs. When [a conflict] does happen, the pharmacist is asked to notify the manager that they have decided not to fill the prescription, and the manager has the obligation to make sure the customer has access to the prescription by another means. ${ }^{326}$

Granted, there are exceptions, and yet, as Judge Richard Posner has argued,

It might seem that [an at-will rule] would leave the employee totally at the employer's mercy, but this is not true. If the employer gets a reputation for arbitrarily discharging employees he will have to pay new employees a premium. Since the employer thus cannot gain in the long run from a policy of arbitrary discharges-it is not effective predatory behavior. ${ }^{327}$

Indeed, even if employers persist in "predatory" behavior to the detriment of employees, the latter usually have the option of organizing or competing to guarantee protection. As Professor Robert Vischer has noted in this

323. GLENDON, supra note 46 , at 171.

324. See Wardle, supra note 6, at 219-226 (discussing the "abuses of the rights of conscience of health care providers").

325. Stein, supra note 12 , at A6.

326. Id. (quoting a spokeswoman for Walgreens).

327. RICHARD A. POSNER, ECONOMIC ANALYSIS OF LAW 342 (6th ed. 2003). 
area, "[p]ushing moral ideals upward through employment and consumer transactions fosters social ties in ways that the top-down enforcement of state-enshrined rules cannot." 328 In the long run, the "tugs and shoves" of employers, employees, and the market not only foster a more authentic dialogue, ${ }^{329}$ they also frame the relative interests at stake in their proper context-i.e., the private sector.

\section{On Balance: Faith and Freedom in the Marketplace}

In the end, the proposal of broad conscience protection is not only inconsistent with existing constitutional and employment law, it also imposes on the modern workplace an accommodation maze without due regard for the long-term interests of both employers and employees (not to mention the public) in working out their conflicts without resort to law. This is not to say that there cannot be exceptions. Indeed, as noted at the start of this article, maybe in the abortion or euthanasia areas, where each side sees their position as non-negotiable, and, further, where both larger cultural agreement and a general lack of litigation combine to suggest minimal impact in any event, ${ }^{330}$ such legally-imposed accommodation would be proper. Moreover, perhaps if conscience measures, like Title VII, were limited to beliefs, or for that matter, even "de minimis" accommodation, one could better justify them on a model that seeks only to neutralize prejudice, not alter valid workplace rules. ${ }^{331}$ And finally, perhaps to the extent protection is offered in connection with public funds (e.g., the Church Amendment), then just as employers and employees are free to choose, then so too should the government through the political process. ${ }^{332}$ Beyond these limited cases, however, such matters are best left to the parties involved.

As the Supreme Court noted recently in clarifying the "reasonable accommodation" requirements of the Americans with Disabilities Act,

[The] objectives [of the Act] demand unprejudiced thought and reasonable responsive reaction on the part of employers and fellow workers alike. They will sometimes require affirmative conduct to promote entry of disabled people into the workforce.

328. Vischer, supra note 10 , at 95.

329. Jamar, supra note 200 , at 728.

330. See, e.g., supra note 31 (discussing the lack of case law for most abortion-related conscience clauses); MYERS, supra note 40, at 314 ("[C]laims for conscience are more likely to succeed the more support for the underlying moral position there is in broader society.").

331. See supra note 281 (discussing the anti-prejudice model of Title VII and exceptions thereto).

332. See, e.g., Rumsfeld v. Forum for Academic and Institutional Rights, Inc., $126 \mathrm{~S}$. Ct. 1297, 1306 (2006) (discussing the wide latitude that Congress has in placing conditions on its financial assistance). 
They do not, however, demand action beyond the realm of the reasonable..$^{333}$

Leaving aside the "undue hardship" limit that also operates in this context, ${ }^{334}$ the Court noted further that an accommodation is reasonable if it "seems reasonable on its face, i.e., ordinarily or in the run of cases." Once again, the current conscience trend offers no such reasonable limit. In fact, even if "ordinarily or in the run of cases" were the test, the market might still be the preferred method of passage. As one observer recently noted,

The issue of refusals in medicine has mostly percolated quietly. Many conflicts are settled informally. Some health-care workers avoid or transfer out of jobs that present moral quandaries. When a conflict arises, co-workers typically step in. Patients often never know it happened. ${ }^{336}$

Indeed, "in framing either a rule of policy or a rule of construction, the focus cannot be on that biased set of cases in which the contract aborts and litigation ensues," 337 but rather in the "run of cases," which, in the conscience setting, are best served by the free, moral choices of both employers and employees, and not by legal impositions of the state.

Leaving things to the market in the conscience arena, of course, does run the risk of a certain level of injustice. And yet, the above discussion calls for a workable framework that serves the interests of all concernedemployer, worker, and public alike. With this in mind, the legal mechanisms that preceded the current conscience trend ultimately work best. In this way, the at-will presumption creates a baseline principle that both employer and employee are presumed to have equal rights to choose whether or not they will work together, and under what terms. ${ }^{338}$ Then, to the extent such equality does not otherwise operate, either as a matter of perception or fact, workers usually have a right to unionize to increase their power $^{339}$ and, in the event of prejudicial abuses of power by employers, seek redress under Title VII and related state laws. ${ }^{340}$ Religious practices

333. US Airways, Inc. v. Barnett, 535 U.S. 391, 401 (2002) (internal citations omitted).

334. See 42 U.S.C. $\S 12112$ (b)(5)(A) (2000) (discussing the requirement to provide reasonable accommodations for a person with a disability unless it poses an "undue hardship" on the employer).

335. Barnett, 535 U.S. at 401.

336. Stein, supra note 21 , at A6.

337. Epstein, supra note 4, at 956.

338. See id. at 957 (noting that "the rights under the contract at will are fully bilateral" and allow the employee to exert influence over the firm).

339. See Morriss, supra note 70, at 1924-25 (discussing the choice to unionize as a factor in determining the relative value of job security in an otherwise at-will employment regime).

340. See 42 U.S.C. $\S 2000 \mathrm{e}-2$ (a) (2000) (stating that it is unlawful to discriminate against 
are, of course, also covered by these provisions, and although protection is confined to "religious" acts and the "de minimis" limit for accommodation typically applies, ${ }^{341}$ the broad meaning of religion given by most courts ${ }^{342}$ coupled with a mandate of "reasonable accommodation" to start (even if only to a "de minimis" extent) offer a balanced measure of protection that respects the interests of employees in a manner more consistent with the anti-prejudice theory otherwise animating Title VII. ${ }^{343}$ Again, perhaps the conscience laws at issue could serve this goal better if they had an "undue hardship" or at least a "reasonable" qualifier that might restrict the impact of the "because I don't feel like it" definition of conscientious objection to which many such laws are susceptible. However, most have no such limitations $\mathrm{s}^{344}$ and, thus, thrust the wider cultural confusion on the meaning of conscience into the marketplace, while imposing the resulting costs almost entirely, and inordinately, on private (i.e., non-state actor) employers.

\section{CONCLUSION}

"[H]uman law does not prohibit everything that is forbidden by the natural law." ${ }^{\text {345 }}$ Perhaps this aphorism from Saint Thomas Aquinas says it best. In fact, the very reality of conscientious objection concedes as much given that, with the rare exception of a worker being asked to commit a crime, it always involves an objection to an otherwise legal act. Of course, it is likely no coincidence that those who support or oppose laws conferring a right to object to a particular act seem to also oppose or support, respectively, the act in general. ${ }^{346}$ Perhaps, as in the case of the abortion-

individuals due to their membership status in a protected class); LARSON, supra note 77, at $\S$ 114.01 (discussing state Fair Employment Practice Laws that are designed to prohibit employment discrimination).

341. See Wardle, supra note 6, at 217-19 (describing the "religious" and "de minimis" limits of Title VII).

342. The EEOC, whose interpretation is followed by most courts (see WOLF, supra note 181 , at 28) defines religion to "include moral or ethical beliefs as to what is right and wrong which are sincerely held with the strength of traditional religious views." 29 C.F.R. $\S$ 1605.1 (2006).

343. See Sonne, supra note 177 , at 1063 (positing that the Title VII "de minimis" standard does not "deviate significantly from the [Title VII] goal of 'equal treatment").

344. See supra note 267 (describing the relatively few limits on existing and pending conscience laws).

345. Thomas Aquinas, Summa Theologica, Part I-II, Q. 96, Art. 2 (Fathers of the English Dominican Province trans., Christian Classics 1981). The Summa was written in the last half of the thirteenth century.

346. Indeed, when one looks generally at those supporting or opposing conscience measures in health care, one could infer a pattern based on underlying opposition or support for some of the procedures at issue. See Stein, supra note 312, at A01 (discussing the politics of "conscience clauses"). 
based laws, this is simply the result of political compromise. However, such reflexive logic can grow suspect when it extends in a more general manner, whether that be in providing a global right to refuse in the private workplace or, to the contrary, in barring any refusals at all.

As noted from the start, this article provides no panacea. Rather, it simply suggests that the trend of open-ended conscience protection that is presently sweeping the nation in the health care arena insufficiently considers the interests of affected employers in at-will authority. The trend is inconsistent with treatments of conscience in law and culture generally, and ignores the fundamental prejudice and public policy bases that otherwise operate in the limited exceptions to the at-will rule that have been developed to this point. Finally, by removing the issue from the deliberative process between employers and their employees, the trend threatens to balkanize both sides in a manner that is good neither for them nor the communities they serve. Conscience is an important and vigorous principle in our common life. For it to remain so on the job, it must act like any other value in an otherwise free and fair system-submit itself to the marketplace of both work and ideas. 